\title{
Thermodynamic activities in silicon binary melts
}

\author{
Jafar Safarian · Leiv Kolbeinsen $\cdot$ Merete Tangstad
}

Received: 30 January 2012/ Accepted: 24 March 2012/Published online: 11 April 2012

(C) The Author(s) 2012. This article is published with open access at Springerlink.com

\begin{abstract}
The thermodynamic activities in the silicon binary melts with $\mathrm{Al}, \mathrm{Ca}, \mathrm{Mg}, \mathrm{Fe}, \mathrm{Ti}, \mathrm{Zn}, \mathrm{Cu}, \mathrm{Ag}, \mathrm{Au}, \mathrm{Sn}$, $\mathrm{Pb}, \mathrm{Bi}, \mathrm{Sb}, \mathrm{Ga}, \mathrm{In}, \mathrm{Pt}, \mathrm{Ni}, \mathrm{Mn}$ and $\mathrm{Rh}$ are studied. The silicon activities along the liquidus are calculated through a quasi-regular solution model using the recently determined liquidus constants for the silicon binary systems. The silicon activities at its melting point are calculated considering regular solution approximation. The activities of the other melt component at the silicon melting point are also calculated through the graphical integration of the GibbsDuhem equation for the activity coefficient, which are further utilized to determine the corresponding activities along the liquidus. The calculated activities are presented graphically, and it is indicated that the results are consistent with the reported activity data in the literature. The activities in the dilute solutions are also calculated graphically. Moreover, the activities of particular dilute solute elements in silicon are calculated through a simple formula, which is a function of the liquidus constants.
\end{abstract}

\section{Introduction}

Silicon has a wide range of applications in metallurgical, semiconductor, photovoltaic (PV), electronic and chemical industries. Silicon transforms to its liquid state during its production and purification through metallurgical processes. In particular, molten silicon is treated through various metallurgical processes, such as slag refining, plasma refining, vacuum refining, and directional solidification

J. Safarian $(\bowtie) \cdot$ L. Kolbeinsen $\cdot$ M. Tangstad

Norwegian University of Science and Technology, Alfred Getz

Vei 2, 7491 Trondheim, Norway

e-mail: Jafar.Safarian@material.ntnu.no to produce solar grade silicon. In these processes, the solute impurities in molten silicon are reduced to very low concentrations to fulfil the requirements of high silicon purity of $99.9999 \mathrm{wt} \%$ for PV applications. Speaking in general, the thermodynamic properties of the silicon melts are crucially important in any silicon-refining technique, and developing basic knowledge on the thermodynamics of silicon melts is needed.

The aim of the present study is to study the chemical activities in silicon binary melts through the application of a novel analytical method without the application of thermodynamic software and programming. The activities of the melt components are calculated, and the obtained results are evaluated with the experimentally and theoretically determined activities in the literature. Moreover, the activities of the silicon binary dilute solutions are determined, which are important regarding the production of solar grade silicon.

\section{Activity calculation methodology}

For a binary system consisting of $\mathrm{Si}$ and element Me with negligible solubility of $\mathrm{Me}$ in $\mathrm{Si}$ at the liquidus temperature ranges, the thermodynamic properties of the melt are related through Eq. (1) [1, 2]:

$\alpha \equiv \frac{R T_{l} \ln \gamma_{\mathrm{Si}}^{l}}{\left(1-X_{\mathrm{Si}}\right)^{2}}=\frac{T_{l} \Delta S_{f, \mathrm{Si}}^{\circ}-\Delta H_{f, \mathrm{Si}}^{\circ}-R T_{l} \ln X_{\mathrm{Si}}}{\left(1-X_{\mathrm{Si}}\right)^{2}}=a-b T_{l}$

where $\Delta H_{f, S i}^{\circ}(50,654.3 \mathrm{~J} / \mathrm{mol})$ and $\Delta s_{f, S i}^{\circ}(30.026 \mathrm{~J} / \mathrm{mol} \mathrm{K})$ are the enthalpy and entropy of fusion of silicon, respectively; $R$ is the universal gas constant; $\gamma_{\mathrm{si}}^{l}$ is the silicon activity coefficient along the liquidus; and $T_{l}$ is the liquidus temperature corresponding to the composition $X_{\mathrm{Si}}$. Constants 
$a$ and $b$ are called the liquidus constants, and parameter $\alpha$ is called here quasi-regular solution constant, which shows a linear function of temperature along the liquidus with respect to the magnitude of the liquidus constants. It is worth mentioning that $\alpha$ is different from the frequently used regular solution constant $\Omega$, which is a constant independent of temperature. In the sub-regular solutions, $\Omega$ is a linear function of composition [3], or even a parabolic function of composition [4]. Obviously, when $\alpha$ is independent of temperature along the liquidus curve, the behaviour of the melt may be similar to the regular solutions. Based on Eq. (1), activities in the silicon binary melts can be calculated by the later described method.

\section{Activity of silicon}

Based on the experimental liquidus data and the application of Eq. (1), the liquidus constants for the 20 silicon binary systems, which are studied here, have recently been calculated [1]. Liquidus is described by Eq. (2), which is obtained by considering the middle part of Eq. (1) as equal to the right-hand side.

$T_{l}=\frac{\Delta H_{f, \mathrm{Si}}^{\circ}+a\left(1-X_{\mathrm{Si}}\right)^{2}}{\Delta S_{f, \mathrm{Si}}^{\circ}-R \ln X_{\mathrm{Si}}+b\left(1-X_{\mathrm{Si}}\right)^{2}}$

Considering the left-hand side of Eq. (1) as equal to the middle part and substituting $T_{l}$ from Eq. (2), an expression for the activity coefficient of silicon along the liquidus curve is derived:

$\ln \gamma_{\mathrm{Si}}^{l}=\frac{a\left(\Delta S_{f, \mathrm{Si}}^{\circ}-R \ln X_{\mathrm{Si}}\right)-b \Delta H_{f, \mathrm{Si}}^{\circ}}{R\left(\Delta H_{f, \mathrm{Si}}^{\circ}+a\left(1-X_{\mathrm{Si}}\right)^{2}\right)}\left(1-X_{\mathrm{Si}}\right)^{2}$

obviously, the activity of silicon along the liquidus can be calculated by Eq. (3) as a function of chemical composition $\left(a_{\mathrm{Si}}^{l}=\gamma_{\mathrm{Si}}^{l} X_{\mathrm{Si}}\right)$. The activity coefficient of $\mathrm{Si}$, which is obtained from Eq. (3), is based on considering a quasiregular solution. In this article, we make a fair approximation through assuming no excess Gibbs free energy change due to increasing the temperature to the higher temperatures than the liquidus for a given chemical composition. Thus, the activity coefficient of Me at temperature $T$ can be calculated:

$\ln \gamma_{\mathrm{Si}}=\frac{T^{l}}{T} \ln \gamma_{\mathrm{Si}}^{l}$

hence, the activity of silicon at a constant temperature, $a_{S i}$, can also be calculated as a function of the chemical composition.

\section{Activity of element Me}

In general, when the activity coefficient of a component in a binary solution such as $\mathrm{Si}$ here is known, the activity coefficient of the other element can be calculated using the Gibbs-Duhem equation, which is applicable under constant pressure and temperature conditions. Along the liquidus curve in the alloy phase diagrams, pressure is constant, while the temperature is changed according to the composition. In principle, the change in the Gibbs free energies in the system is expressed by Eq. (5):

$\mathrm{d} G=V \mathrm{~d} p-S \mathrm{~d} T+\sum_{i} \mu_{i} \mathrm{~d} n_{i}$

where $V$ is volume; $S$ is the entropy; $p$ and $T$ are the pressure and the temperature of the system, respectively; and $\mu_{i}$ denotes the chemical potential of the solution component with molar concentration of $n_{i}$. On the other hand, the total Gibbs free energy of the solution is expressed as

$G=\sum n_{i} \bar{G}_{i}$

Where $\bar{G}_{i}\left(=\mu_{i}\right)$ is the partial molar Gibbs energy of component $i$ in solution. Differentiating Eq. (6) and combining it with Eq. (5) gives the following expression for the $\mathrm{Si}-\mathrm{Me}$ melts along the liquidus under constant pressure:

$n_{\mathrm{Si}} \mathrm{d} \bar{G}_{\mathrm{Si}}+n_{\mathrm{Me}} \mathrm{d} \bar{G}_{\mathrm{Me}}=S \mathrm{~d} T$

since temperature is changed along the liquidus and also entropy of the system can have any value, the well-known Gibbs-Duhem equation for activity coefficient integration (Eq. 8) cannot be derived along the liquidus of the silicon binary system. The activity coefficient of Me can, however, be calculated at a constant temperature by graphical Gibbs-Duhem integration according to Eq. (8) by considering the determined silicon activity coefficient at this temperature. This means that the silicon activity coefficient at this temperature is first calculated by assuming regular solution behaviour for silicon by Eq. (4). In addition, the activity coefficient of Me along the liquidus can also be calculated by assuming regular solution behaviour for Me.

$\ln \gamma_{\mathrm{Me}}=-\int_{\ln \gamma_{\mathrm{Si}} \mathrm{at} X_{\mathrm{Si}}=1}^{\ln \gamma_{\mathrm{Si}} \text { at } X_{\mathrm{Si}}=X_{\mathrm{Si}}} \frac{X_{\mathrm{Si}}}{X_{\mathrm{Me}}} \mathrm{d} \ln \gamma_{\mathrm{Si}}$

Regarding the previously calculated $a$ and $b$ constants for silicon binary systems [1], which are re-presented here in Table 1 , the activities along the liquidus and at the silicon melting point $\left(1,414^{\circ} \mathrm{C}\right)$ are calculated by means of the calculation sequences shown in Fig. 1. The activities are calculated using Excel spreadsheet, and the results are plotted in graphs. It is worth noting that the activities are calculated and presented with reference to the pure liquid melt components as the standard state. 
Table 1 Liquidus constants and eutectic compositions for silicon binary systems [1]

\begin{tabular}{lccll}
\hline System & $a$ & & $T_{\text {eut }}^{\mathrm{a}}(\mathrm{K})$ & $X_{\mathrm{Si}, \text { eut }}$ \\
\hline $\mathrm{Si}-\mathrm{Al}$ & -9789.7 & 3.7402 & 850.1 & 0.119 \\
$\mathrm{Si}-\mathrm{Ca}$ & $-83,820$ & -0.2271 & 1,296 & 0.694 \\
$\mathrm{Si}-\mathrm{Mg}$ & $-73,857$ & -32.612 & 1,217 & 0.527 \\
$\mathrm{Si}-\mathrm{Fe}$ & $-99,915$ & -47.18 & 1,479 & 0.724 \\
$\mathrm{Si}-\mathrm{Ti}$ & $-32,8815$ & -167.32 & 1,591 & 0.87 \\
$\mathrm{Si}-\mathrm{Zn}$ & 29,206 & 16.26 & 692.2 & $2.5 \times 10^{-4}$ \\
$\mathrm{Si}-\mathrm{Cu}$ & $-41,822$ & -24.056 & 1,075 & 0.304 \\
$\mathrm{Si}-\mathrm{Ag}$ & $-32,763.1$ & -32.42 & 1,108 & 0.116 \\
$\mathrm{Si}-\mathrm{Au}$ & $-49,248$ & -24.058 & 633 & 0.183 \\
$\mathrm{Si}-\mathrm{Pt}$ & $-197,194$ & -93.921 & 1,220 & 0.656 \\
$\mathrm{Si}-\mathrm{Sn}$ & 31,162 & 4.0289 & 505 & $2 \times 10^{-7}$ \\
$\mathrm{Si}-\mathrm{Pb}$ & 79,639 & 17.079 & 600 & $1.3 \times 10^{-9 b}$ \\
$\mathrm{Si}-\mathrm{Bi}$ & 61,648 & 8.3531 & 544 & $1.7 \times 10^{-9 b}$ \\
$\mathrm{Si}-\mathrm{Sb}$ & 14,273 & -5.99 & 902.7 & $3.2 \times 10^{-3}$ \\
$\mathrm{Si}-\mathrm{Ga}$ & 14,844 & 4.75 & 302.8 & $3 \times 10^{-10}$ \\
$\mathrm{Si}-\mathrm{In}$ & 46,903 & 13.97 & 429.6 & $2.5 \times 10^{-10}$ \\
$\mathrm{Si}-\mathrm{Pd}$ & $-73,424$ & -28.385 & 1,165 & 0.52 \\
$\mathrm{Si}-\mathrm{Ni}$ & $-89,383$ & -36.856 & 1,266 & $0.591^{\mathrm{c}}$ \\
$\mathrm{Si}-\mathrm{Mn}$ & $-123,424$ & -64.86 & 1,415 & 0.674 \\
$\mathrm{Si}-\mathrm{Rh}$ & $-201,331$ & -102.06 & 1,333 & 0.686 \\
\hline $\mathrm{Fr}$ & & & &
\end{tabular}

${ }^{\text {a }}$ From literature

b Monotectic

c Peritectic

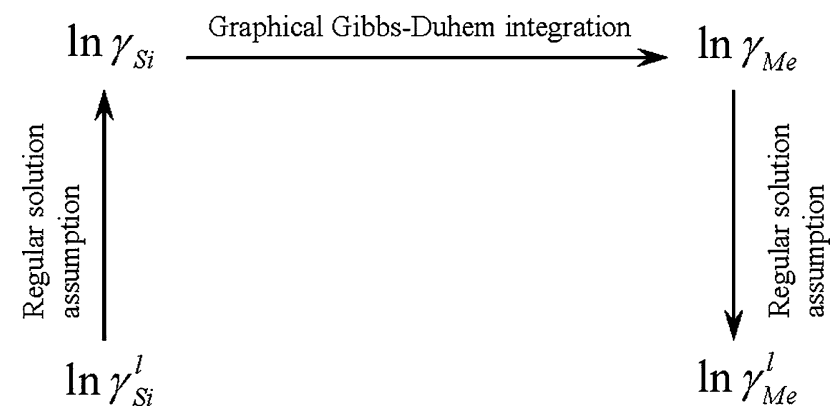

Fig. 1 The calculation sequence of the activity coefficients of $\mathrm{Si}$ and Me along the liquidus $\left(\gamma_{\mathrm{Si}}^{l}, \gamma_{\mathrm{Me}}^{l}\right)$ and silicon melting point $\left(\gamma_{\mathrm{Si}}, \gamma_{\mathrm{Me}}\right)$

\section{Results and discussion}

Activities in the silicon melts

The activities calculated for the silicon binary melts are graphically presented. Moreover, they are evaluated and discussed with regard to the literature data.

\section{Si-Al alloys}

Activities of $\mathrm{Al}$ and $\mathrm{Si}$ in their binary melts have been measured by electromotive force (emf) method using concentration cells of the $\mathrm{Al}_{\text {liq }}\left|\mathrm{AlCl}_{3}, \mathrm{KCl}+\mathrm{NaCl}\right|(\mathrm{Al}$, $\mathrm{Si})_{\text {liq }}[5,6]$, and by the application of Knudsen cell mass spectrometry [7, 8]. The activity coefficient of $\mathrm{Al}$ in dilute solution with molten silicon alloys has also been measured by Miki et al. by chemical equilibrium technique and Knudsen effusion method [9, 10]. The measured activity data of these cited studies are presented in Fig. 2 together with the calculated activities proposed in other studies [11-13]. The presented curve for Gizenko et al. [13] was calculated using their measured enthalpies of the formation of $\mathrm{Al}-\mathrm{Si}$ alloys at $1,820 \mathrm{~K}\left(1,547^{\circ} \mathrm{C}\right)$. using calorimetric technique and assuming regular solution model. Th activity data reported for $\mathrm{Al}$ in silicon by Iwata et al. [14] were found to be not very accurate, since they show large positive deviation from the ideal solution. The calculated activities for $\mathrm{Si}-\mathrm{Al}$ solutions along the liquidus of the present study are also shown in Fig. 2. It is seen that the calculated activity changes according to the composition are consistent over the whole range of composition regarding the other studies. It is worth mentioning that the calculation of the silicon activities along the liquidus was performed from pure silicon to the eutectic composition in the $\mathrm{Si}-\mathrm{Al}$ system at $X_{\mathrm{Si}}=0.12$ (Table 1) and also to the lower silicon concentrations. It was observed that the silicon activity curve remains continuous for temperatures below the eutectic enabling computation of the silicon activities for hypothetical melts below this temperature. Therefore, the calculations were done in the whole range of composition. This method was also applied for the other melts, and the hypothetical silicon activities along the extended liquidus from the eutectic coordinates (Table 1) were calculated. These calculations were performed for the composition in which the absolute temperature for the liquidus is obtained through Eq. (2), and the feasible silicon activity curves from this point were extrapolated to lower silicon concentrations.

The behaviour of $\mathrm{Al}$ in low concentrations, which is important for solar grade silicon materials, can be seen in Fig. 2c. The activity curve for Miki et al. was calcu lated using their reported activity data: $\ln \gamma_{\mathrm{Si}}^{\circ}=-3610 /$ $T+0.452$, and $\varepsilon_{\mathrm{Al}}^{\mathrm{Al}}=100,000 / T-40.1$ [10] at $1,700 \mathrm{~K}$ $\left(1,427^{\circ} \mathrm{C}\right)$. There is a good correlation between the calculated curve of the present study and the calculated curve from their activity data for the dilute solutions with aluminium molar fractions smaller than $X_{\mathrm{Al}}=0.05$. The calculated activity curve fits also with the measured $\mathrm{Al}$ activities in silicon dilute solutions [9].

\section{Si-Ca alloys}

Activities of $\mathrm{Si}-\mathrm{Ca}$ melts have been established by Wynnyckyj and Pidgeon [15] and Schurmann et al. [16] through the measurement of the calcium pressure over $\mathrm{Si}-\mathrm{Ca}$ melts. 
Fig. 2 Activities of $\mathrm{Si}$ and $\mathrm{Al}$ along the liquidus and at the silicon melting point
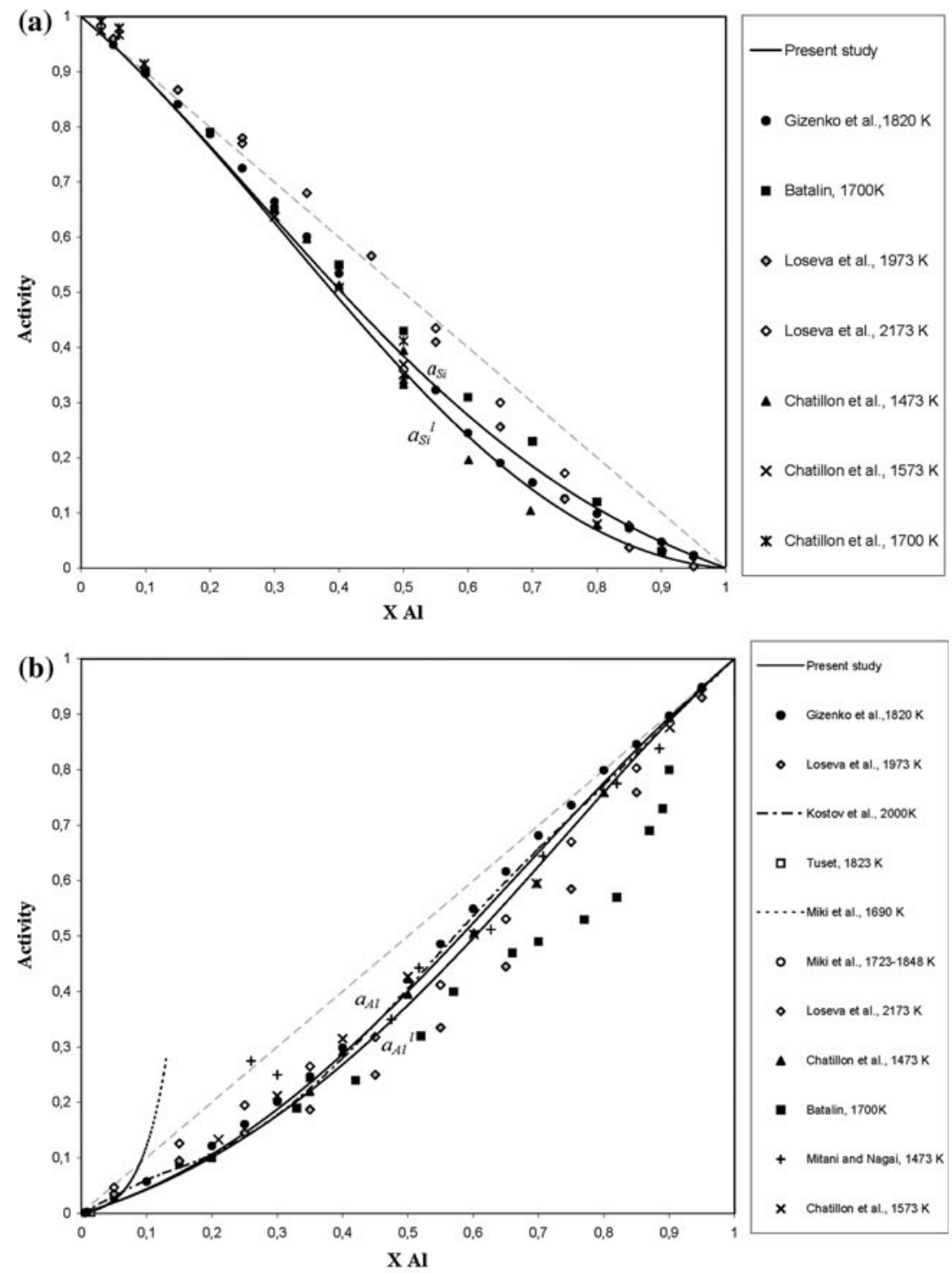

\author{
(c)
}
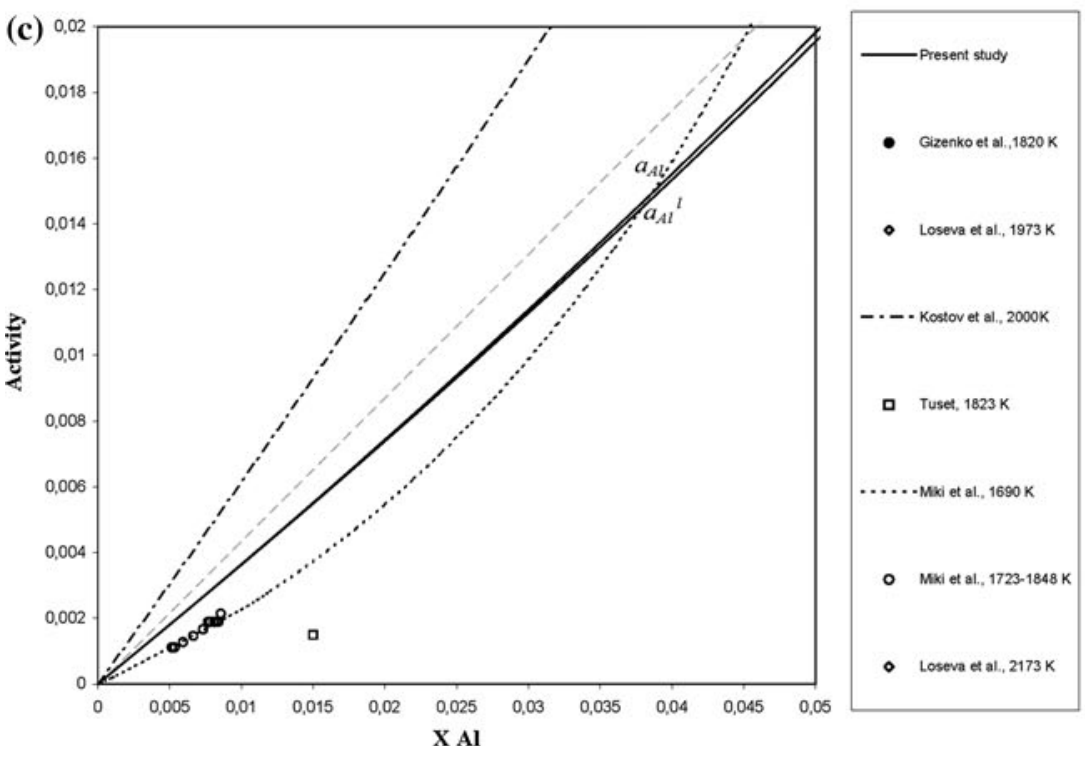
They measured the activity of calcium and calculated the activity of $\mathrm{Si}$ by Gibbs-Duhem equation. The activity values have also been obtained through the application of the measured enthalpies of mixing of liquid silicon and calcium by calorimetry technique [17]. The activity of $\mathrm{Ca}$ in dilute solution with silicon has also been measured through chemical equilibrium technique and Knudsen effusion method $[9,10]$. The chemical equilibrium of liquid silicon with slags has also been used for activity determination $[11,18]$. Based on the thermodynamic data for $\mathrm{Si}-\mathrm{Ca}$ system, the activities for its liquid alloys have been also calculated through other studies $[19,20]$. The calculated activities of the present study along with the literature data are shown in Fig. 3a. It is observed that there is a good agreement between the literature data and the calculated activities of the present study using the liquidus data. It is seen that the $\mathrm{Si}-\mathrm{Ca}$ liquid solutions show large negative behaviour from the Raoultian. The calculated activity curves here at the silicon melting point $(1,687 \mathrm{~K})$ are in agreement with the measurements done by Schurmann et al. [16]. The calculated activities for $\mathrm{Ca}$ along the liquidus are only presented to the eutectic composition
Fig. 3 Activities of $\mathrm{Si}$ and $\mathrm{Ca}$ along the liquidus and at the silicon melting point
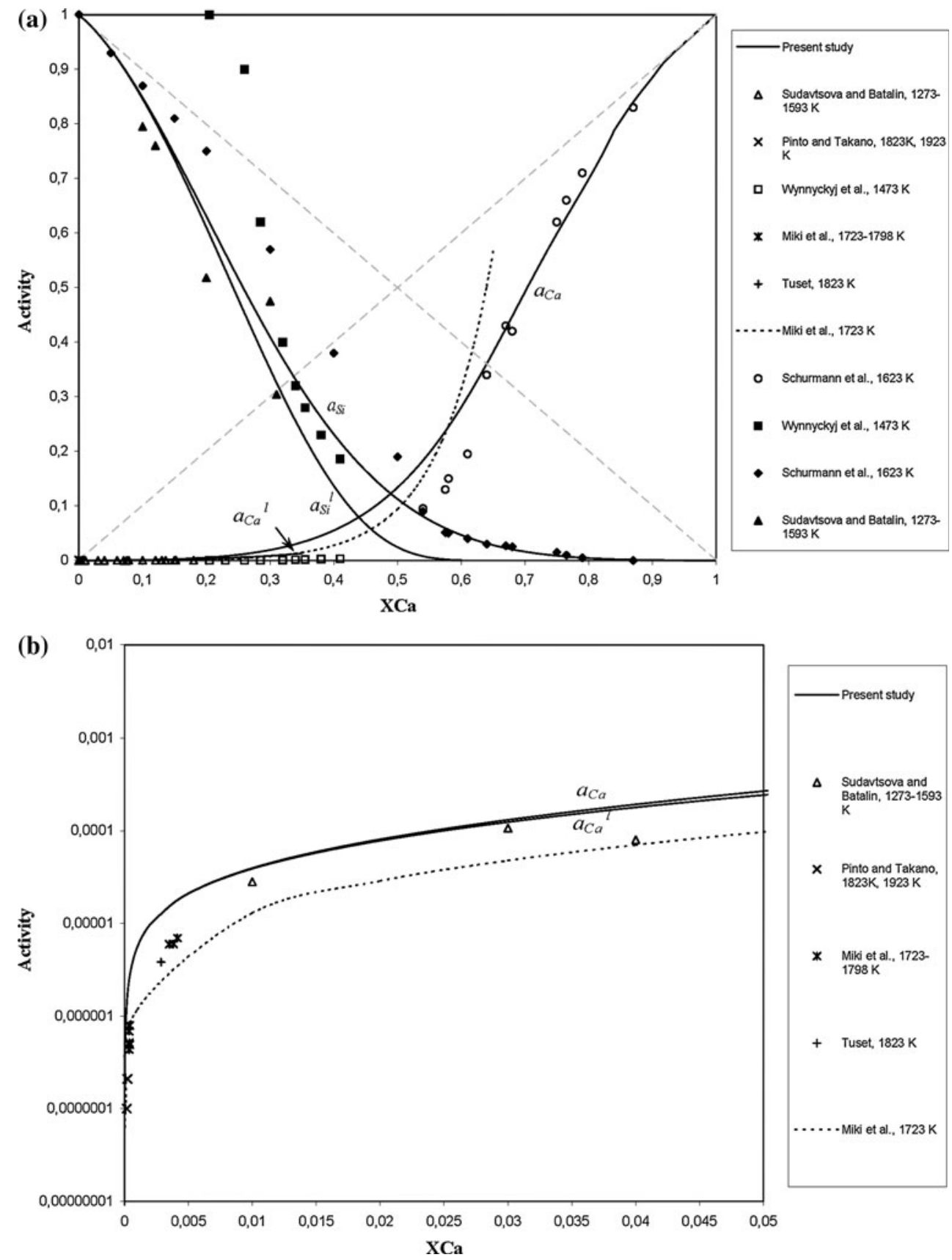
$\left(X_{\mathrm{Ca}}=0.31\right)$, since no real melt exists in higher calcium concentrations along the liquidus obtained by Eq. (2).

The activity data for $\mathrm{Si}-\mathrm{Ca}$ melts in low calcium concentrations are relatively close as seen in Fig. 3b. The present calculated activities are consistent with the experimental measurements $[10,17]$. In addition, the present calculation results are relatively close to the calculated curves obtained using the reported activity data: $\ln \gamma_{\mathrm{Ca}}^{\circ}=$ -6.926, and $\varepsilon_{\mathrm{Ca}}^{\mathrm{Ca}}=10.858[10,21]$ at $1,723 \mathrm{~K}\left(1,450{ }^{\circ} \mathrm{C}\right)$.

\section{Si-Mg alloys}

The activities in $\mathrm{Si}-\mathrm{Mg}$ liquid alloys were measured by the isopiestic method [22], phase diagram data [23], and emf technique $[24,25]$. The activity of $\mathrm{Mg}$ in dilute solution with silicon has been measured through chemical equilibrium technique and Knudsen effusion method $[9,10]$. The calculated activities of the present study are compared with the other studies in Fig. $4 \mathrm{a}$. It is seen that $\mathrm{Si}-\mathrm{Mg}$ liquid
Fig. 4 Activities of $\mathrm{Si}$ and $\mathrm{Mg}$ along the liquidus and at the silicon melting point (a)
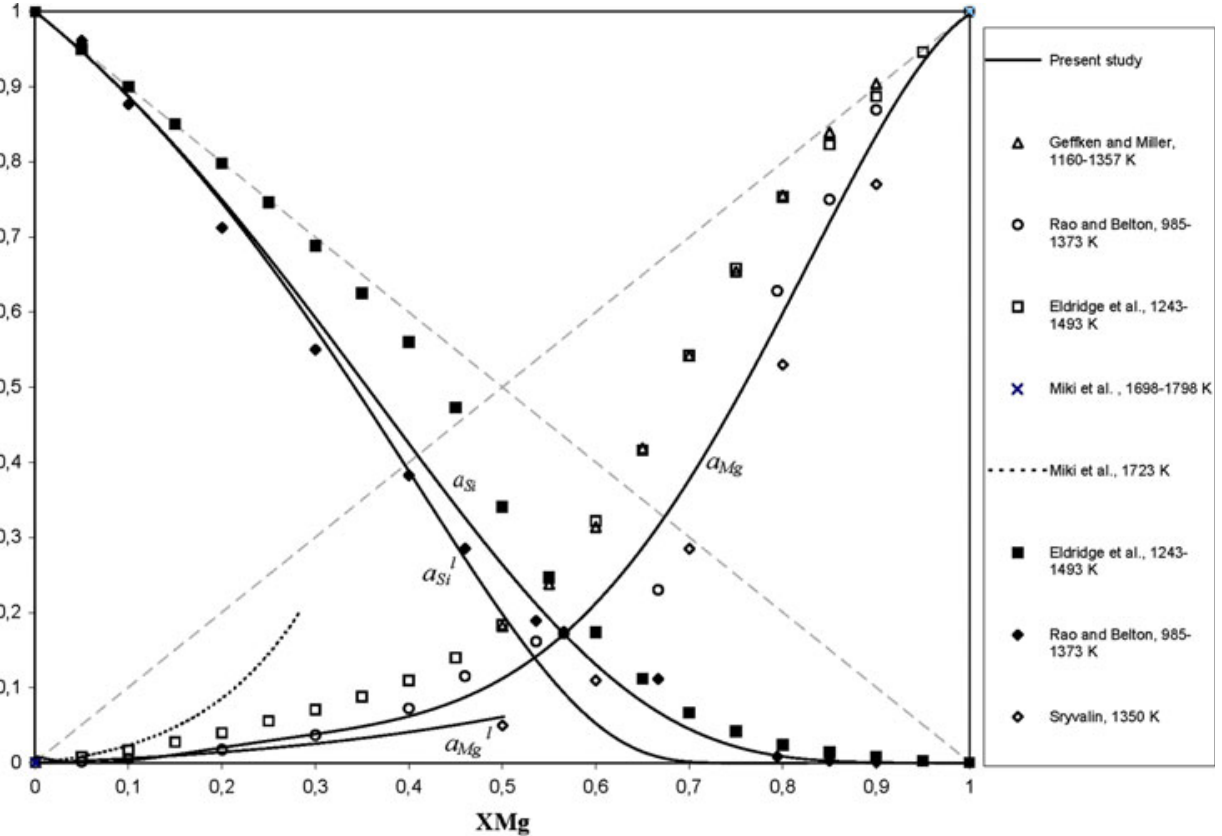

(b)

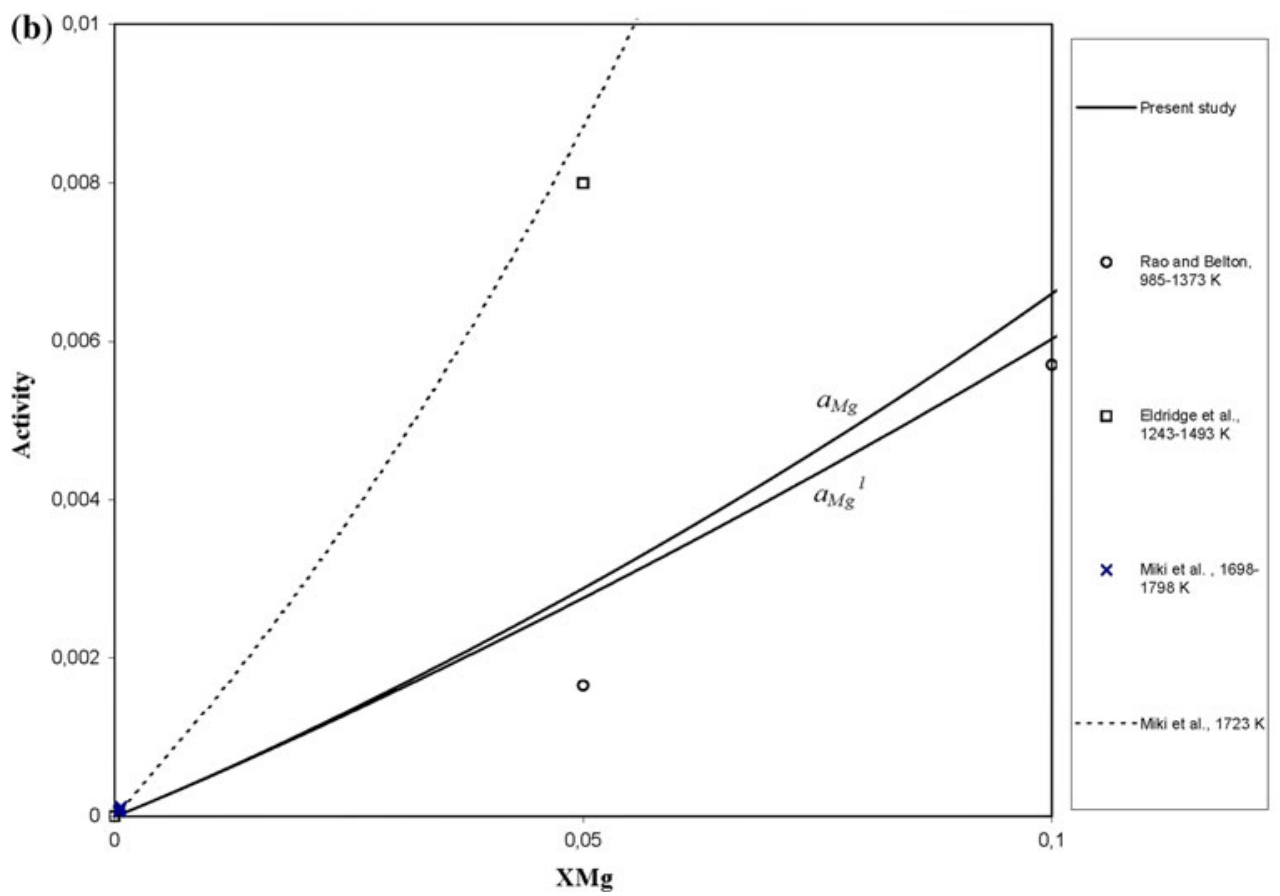


alloys show negative deviation from the Raoult's law. The calculated $\mathrm{Si}$ and $\mathrm{Mg}$ activities are closer to those of the Rao and Belton method [25], which are assumed to be the most accurate among the previous studies. The calculated $\mathrm{Mg}$ activities in the dilute solutions are also shown in Fig. $4 \mathrm{~b}$ The calculated $\mathrm{Mg}$ activities using the reported activity data by Miki et al. [10]: $\ln \gamma_{\mathrm{Mg}}^{\circ}=-2.048$, and $\varepsilon_{M g}^{M g}=6.02$ at $1,723 \mathrm{~K}\left(1,450{ }^{\circ} \mathrm{C}\right)$ are also illustrated in this figure. The obtained $\mathrm{Mg}$ activities in low concentrations are less than half of the measured and predicted values by Miki et al. $[9,10]$.

Fig. 5 Activities of $\mathrm{Si}$ and $\mathrm{Fe}$ along the liquidus and at the silicon melting point

\section{Si-Fe alloys}

The activities of $\mathrm{Fe}$ and $\mathrm{Si}$ over the whole range of composition have been measured using chemical equilibrium [26] and galvanic cells [27, 28]. Moreover, the activities of $\mathrm{Fe}$ in dilute concentrations have been studied through equilibrium techniques $[11,29]$. The calculated activity curves in this study are shown in Fig. 5. According to the results, $\mathrm{Si}-\mathrm{Fe}$ melts show negative deviational behaviour from the ideal solution. There is a good correlation between the calculated silicon activities here and the

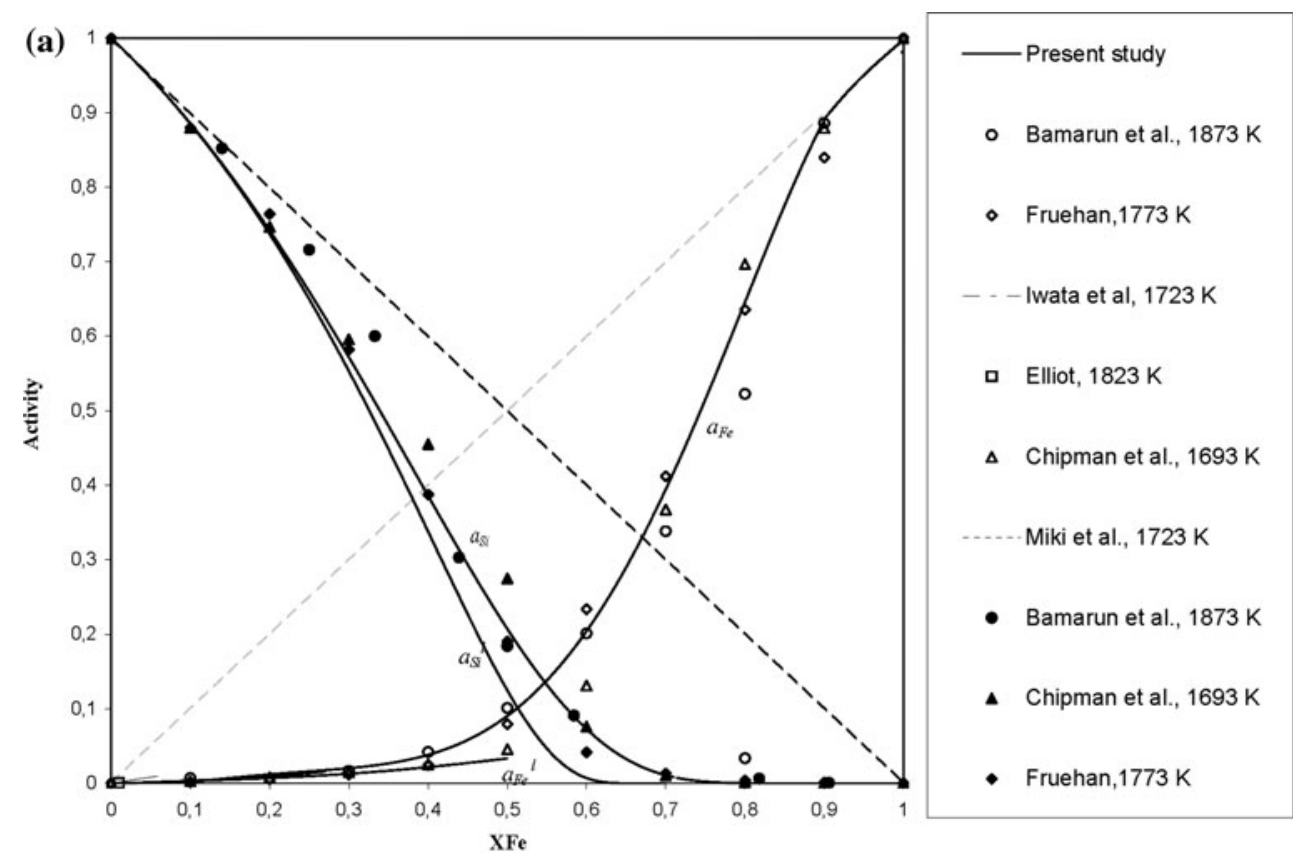

(b)

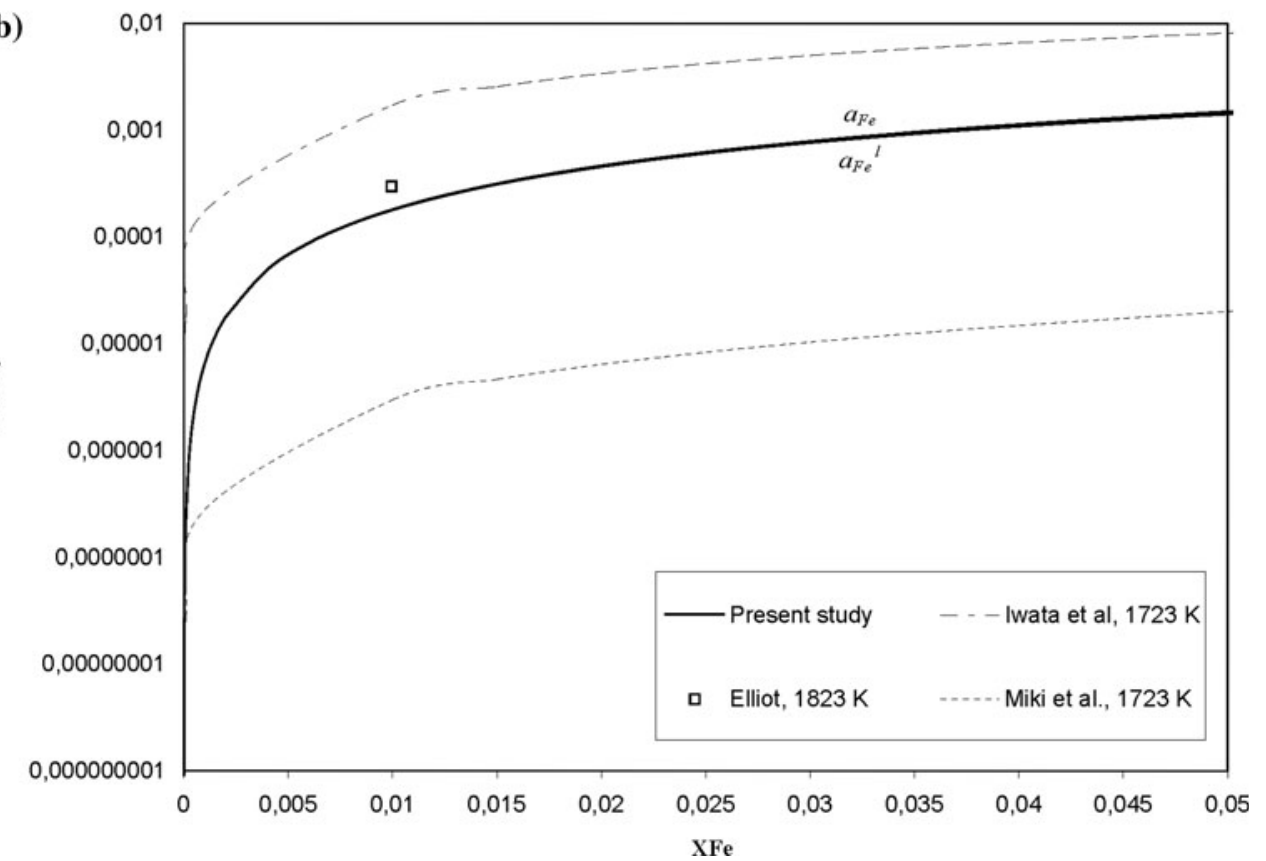


activity measurements of Chipman et al. [26] and Fruehan [27]. In order to evaluate the calculated iron activities in the low concentrations, the $\mathrm{Fe}$ activities in molten $\mathrm{Si}$ were calculated using the reported activity data proposed by Miki et al. [29] and Iwata et al. [14]. According to their reported thermodynamic data, we have $\ln \gamma_{\mathrm{Fe}}^{\circ}=-3.558$, $\varepsilon_{\mathrm{Fe}}^{\mathrm{Fe}}=3.17$ [29] and $\ln \gamma_{\mathrm{Fe}}^{\circ}=-1.75, \varepsilon_{\mathrm{Fe}}^{\mathrm{Fe}}=-1.37$ [14] at $1,723 \mathrm{~K}$. It is observed that the calculated iron activities in low concentrations of the present study are located between the calculated activity curves obtained by their data (Fig. 5b).

\section{Si-Ti alloys}

The thermodynamic activities in $\mathrm{Si}-\mathrm{Ti}$ system has been studied previously in a few studies. Sudavtsova et al. [30] determined the enthalpy of mixing of the silicon-rich alloys by isothermal calorimetric technique and determined the silicon activities. Miki et al. [29] determined the activity data for titanium in liquid silicon using the equilibrium technique. The activity of $\mathrm{Ti}$ in low concentrations and the activities of $\mathrm{Si}$ and $\mathrm{Ti}$ in the whole range of composition have also been calculated by Iwata et al. [14] and Kostov et al. [12], respectively. In the latter study, the calculations were done using FactSage thermodynamic software. The present calculated activities for silicon along the liquidus and at the silicon melting point are shown in Fig. 6 together with those of the literature studies for silicon. The results are consistent with regard to the silicon activities measured by Sudavtsova et al. and the suggested curve by Kostove et al. for 2,000 K. Obviously, all the studies indicate significant negative deviation from the ideal solution for the $\mathrm{Si}-\mathrm{Ti}$ liquid alloys. Since the silicon activities were calculated for high silicon concentrations and there is very high negative deviation from the ideal solution, it was difficult to extend the calculated silicon activity curves over the whole range of composition, and therefore the Gibbs-Duhem integration for $\mathrm{Ti}$ activity determination was not done.

\section{Si-Zn alloys}

The $\mathrm{Si}-\mathrm{Zn}$ phase diagram is a simple eutectic system and the eutectic is located on $\mathrm{Zn}$ portion at $X_{\mathrm{Zn}}=0.99975$. No experimental measurement on the activities of $\mathrm{Si}-\mathrm{Zn}$ melts was found in the literature and the calculated activities for $\mathrm{Zn}$ and $\mathrm{Si}$ in $\mathrm{Si}-\mathrm{Zn}$ system are shown in Fig. 7. It is observed that $\mathrm{Si}-\mathrm{Zn}$ melts indicate small positive deviation from the Raoultian behaviour.

\section{$\mathrm{Si}-\mathrm{Cu}$ alloys}

The thermodynamic properties of $\mathrm{Si}-\mathrm{Cu}$ melts have been studied by calorimetry technique [31-33]. Activities in these melts have also been measured using emf technique [34] and Knudsen-cell mass spectrometry [35, 36]. The calculated activities for both $\mathrm{Si}$ and $\mathrm{Cu}$ of the present study are illustrated in Fig. 8 together with the literature data. The silicon activity data for Batalin and Sudavtsova [32] are obtained with regard to their reported partial molar Gibbs energy of mixing with assuming the regular solution model. It is worth mentioning that the reported partial
Fig. 6 Activity of Si along the liquidus and at the silicon melting point in $\mathrm{Si}-\mathrm{Ti}$ melts

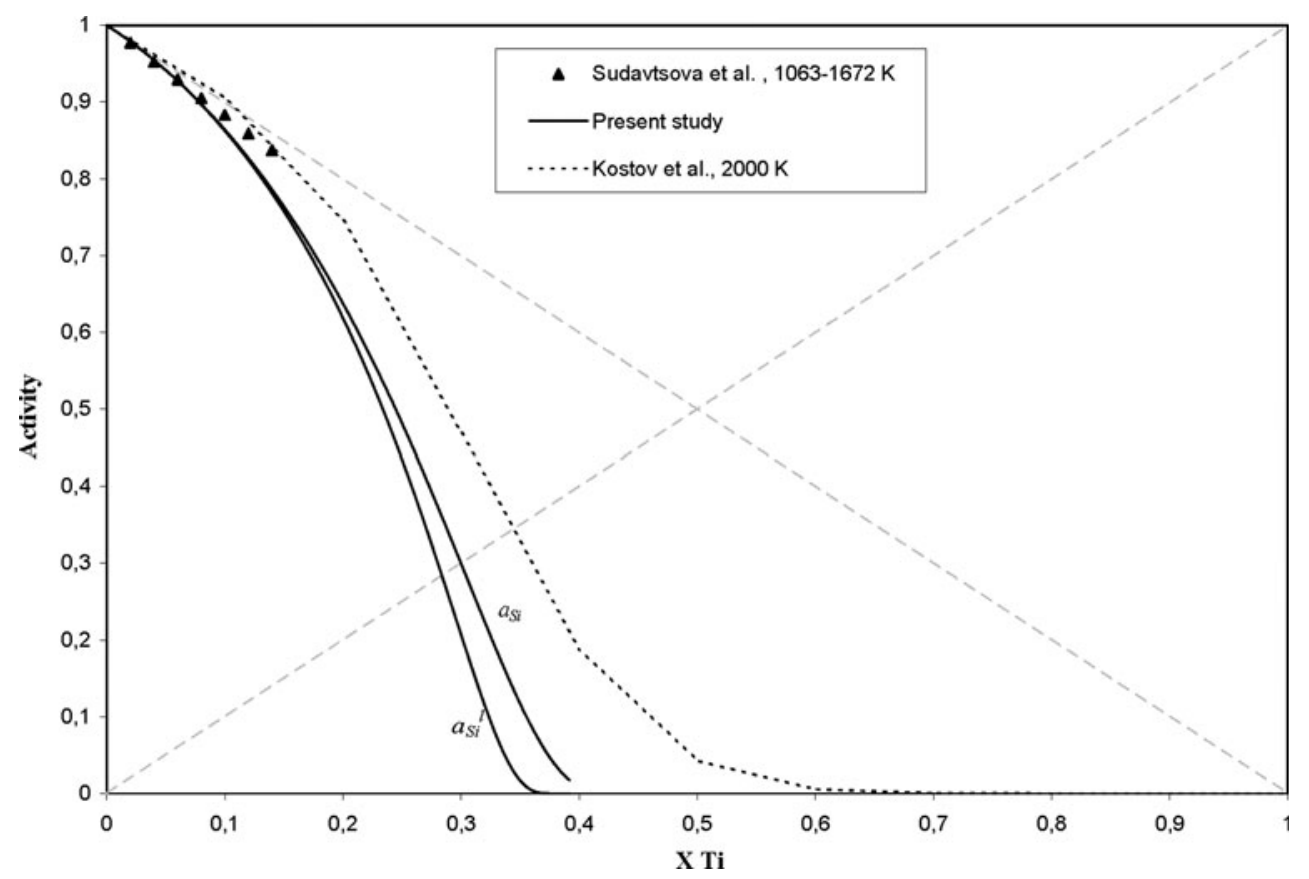


Fig. 7 Activities of $\mathrm{Si}$ and $\mathrm{Zn}$ along the liquidus and at the silicon melting point
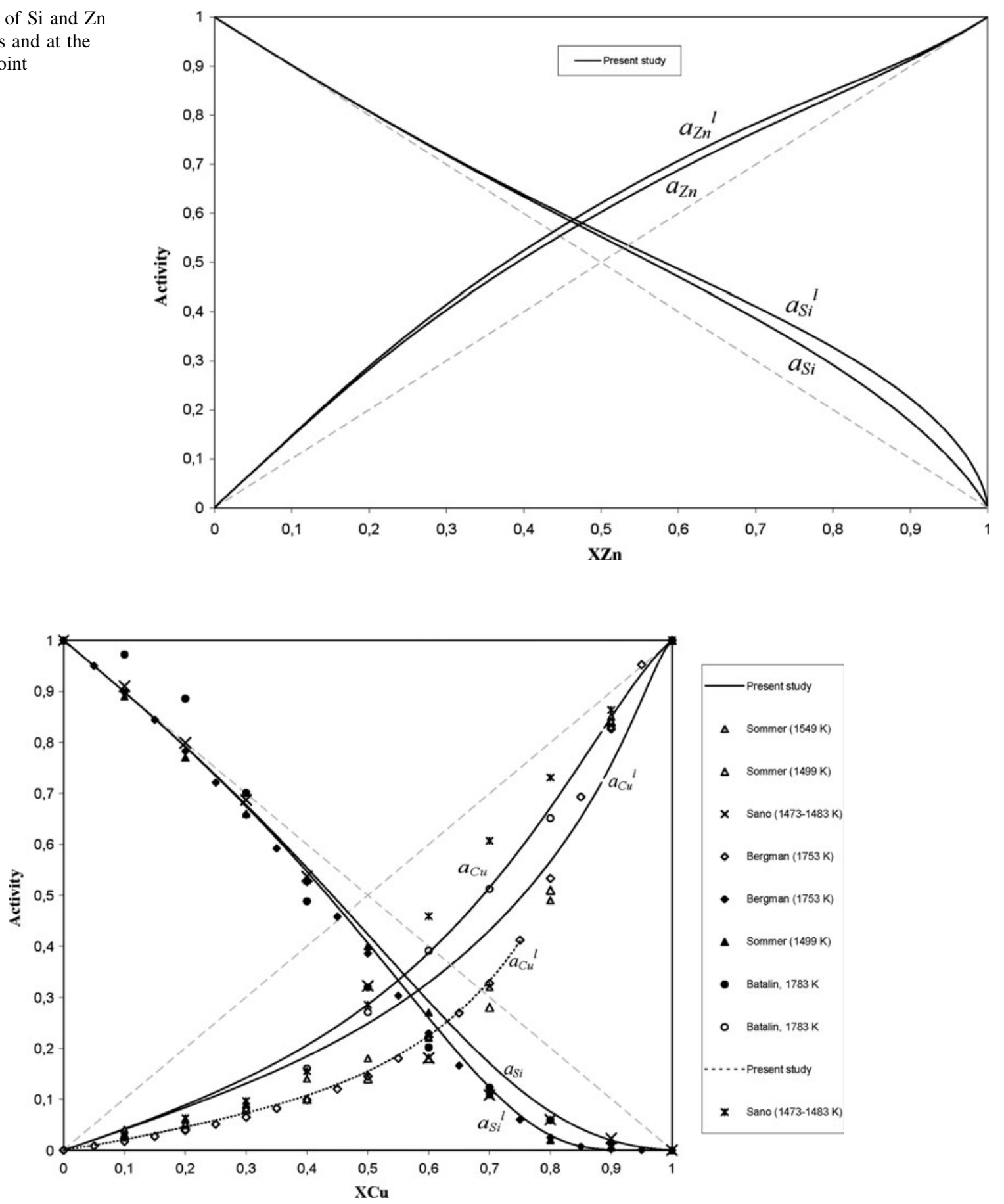

Fig. 8 Activities of $\mathrm{Si}$ and $\mathrm{Cu}$ along the liquidus and at the silicon melting point

molar enthalpies of formation of silicon by Castanet [31] were used to calculate the activities, but the results were significantly different with the other studies and they are not presented here. It is seen that the calculated silicon activities along the liquidus are close to the majority of the literature data [34-36], whereas the calculated silicon activities at the silicon melting point are higher than the literature data for high silicon concentrations. This may be the reason of obtaining higher copper activities than the more reliable literature data $[35,36]$ through the GibbsDuhem integration on the silicon activities at $1,414{ }^{\circ} \mathrm{C}$. The obtained activity curves for the copper close to the results for Batalin and Sudavtsova may be due to the application of the regular solution model to calculate the $\mathrm{Cu}$ activities from their thermodynamic data. Considering the copper activities reported by Bergman and 
Sommer as the more accurate data, we may argue that the silicon activity in $\mathrm{Si}-\mathrm{Cu}$ melts is weakly affected by temperature and the applied regular solution approximation cannot be applied to calculate silicon activity at $1,414{ }^{\circ} \mathrm{C}$. Thus, assuming no significant change of the silicon activities by temperature and performing the Gibbs-Duhem integration directly on the calculated activity coefficients along the liquidus, the copper activities can be calculated as shown by the dotted curve in Fig. 8, which accords with the literature data. Thus, we may consider this copper activity curve as the more accurate one for several temperature ranges.

\section{Si-Ag alloys}

The thermodynamic properties of $\mathrm{Si}-\mathrm{Ag}$ melts have been studied through several experimental studies [37-41]. Hager [37] calculated $\mathrm{Si}$ and $\mathrm{Ag}$ activities using the liquidus data and considering the regular solution model; their calculated Ag activities are illustrated in Fig. 9. Activity coefficients of $\mathrm{Si}$ in Ag were determined through equilibrium technique by Torkdugan and Grieveson [38] and they reported positive deviations from the ideal solution for the dilute solutions of this system. The partial thermodynamic properties of $\mathrm{Ag}-\mathrm{Si}$ alloys have been also determined through the partial pressure measurement of silver [39]. Similarly, the Ag activities have been determined through partial pressure measurement of silver, and consequently the $\mathrm{Si}$ activities determination by Gibbs-Duhem equation [40]. The activity of $\mathrm{Si}$ in $\mathrm{Si}-\mathrm{Ag}$ alloys has been also determined by emf technique followed by $\mathrm{Ag}$ activity determination by Gibbs-Duhem equation [41]. The calculated silicon activities for $\mathrm{Si}-\mathrm{Ag}$ melts in this study are consistent with the literature data as seen in Fig. 9.

\section{Si-Au alloys}

The activities in $\mathrm{Si}-\mathrm{Au}$ melts have been calculated by the phase diagram data [42, 43], and using Knudsen-cell mass spectrometry [44]. The calculated activity curves in this study for the $\mathrm{Si}-\mathrm{Au}$ system are shown in Fig. 10 in comparison with the other studies. The data of [43] were taken from Elliot and Shunk [45]. Negative deviation from the ideal solution is observed for these melts. The calculated activity curves of the present study are based on the reliable liquidus data [1] and must be in high accuracy in comparison with the other studies [42, 43].

\section{Si-Pt alloys}

The calculated activities for silicon in the $\mathrm{Si}-\mathrm{Pt}$ melts are shown in Fig. 11. The silicon activities along the liquidus and to a little higher Pt concentrations than the eutectic composition at $X_{\mathrm{Pt}}=0.3436$ were calculated by Eq. (3), which were then used to calculate the silicon activities at the silicon melting point by Eq. (4). It is observed that $\mathrm{Si}-$ Pt molten alloys show large negative deviation from the ideal solution. Unfortunately, no experimental measurement for the activities in this system was found in the literature. However, the calculated activity curve for $\mathrm{Si}$ in the $\mathrm{Si}-\mathrm{Pt}$ alloys is close to the estimated activities proposed by $\mathrm{Xu}$ et al. [46], and this may support the fact that the
Fig. 9 Activities of $\mathrm{Si}$ and $\mathrm{Ag}$ along the liquidus and at the silicon melting point

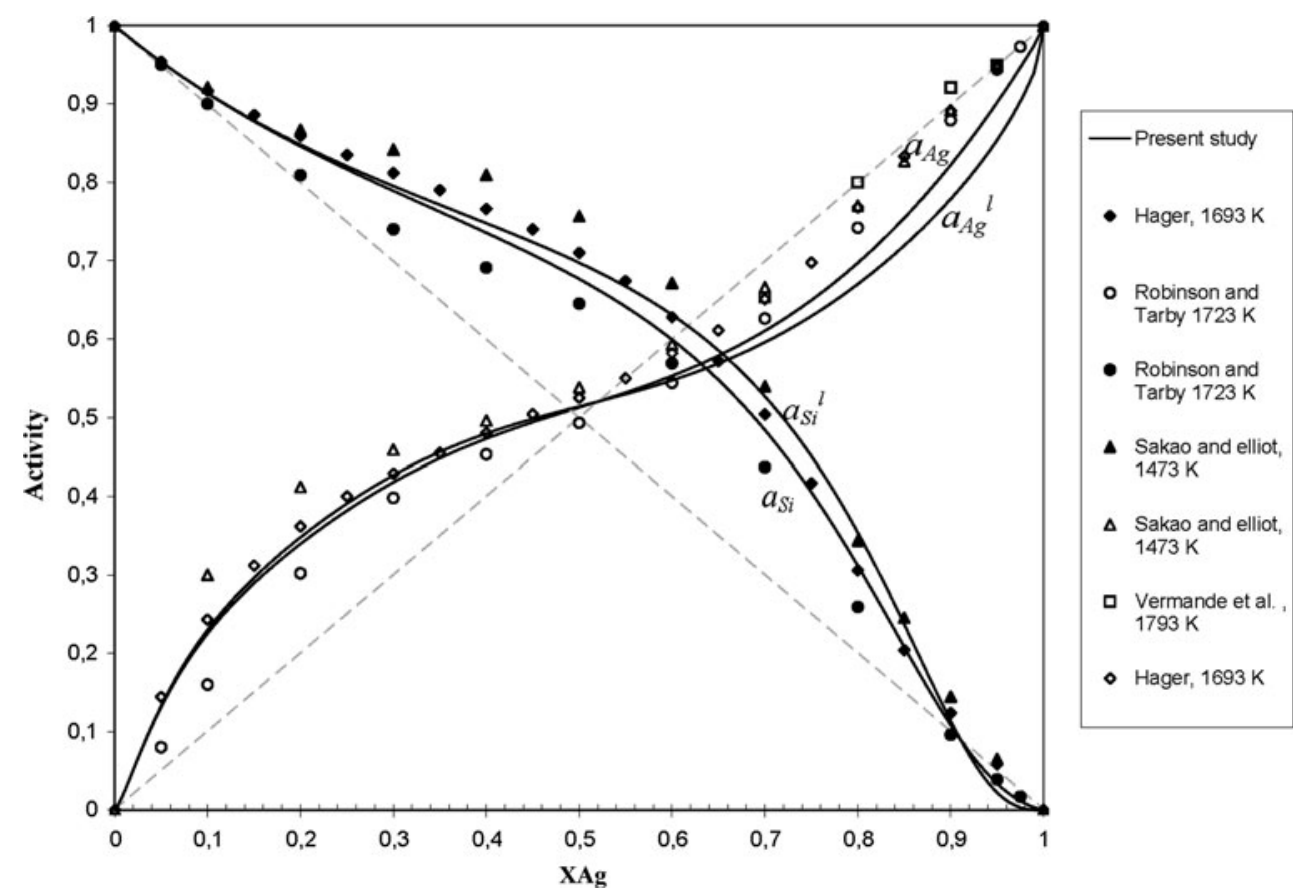


Fig. 10 Activities of $\mathrm{Si}$ and $\mathrm{Au}$ along the liquidus and at the silicon melting point
Fig. 11 Activity of Si along the liquidus and at the silicon melting point in Si-Pt melts
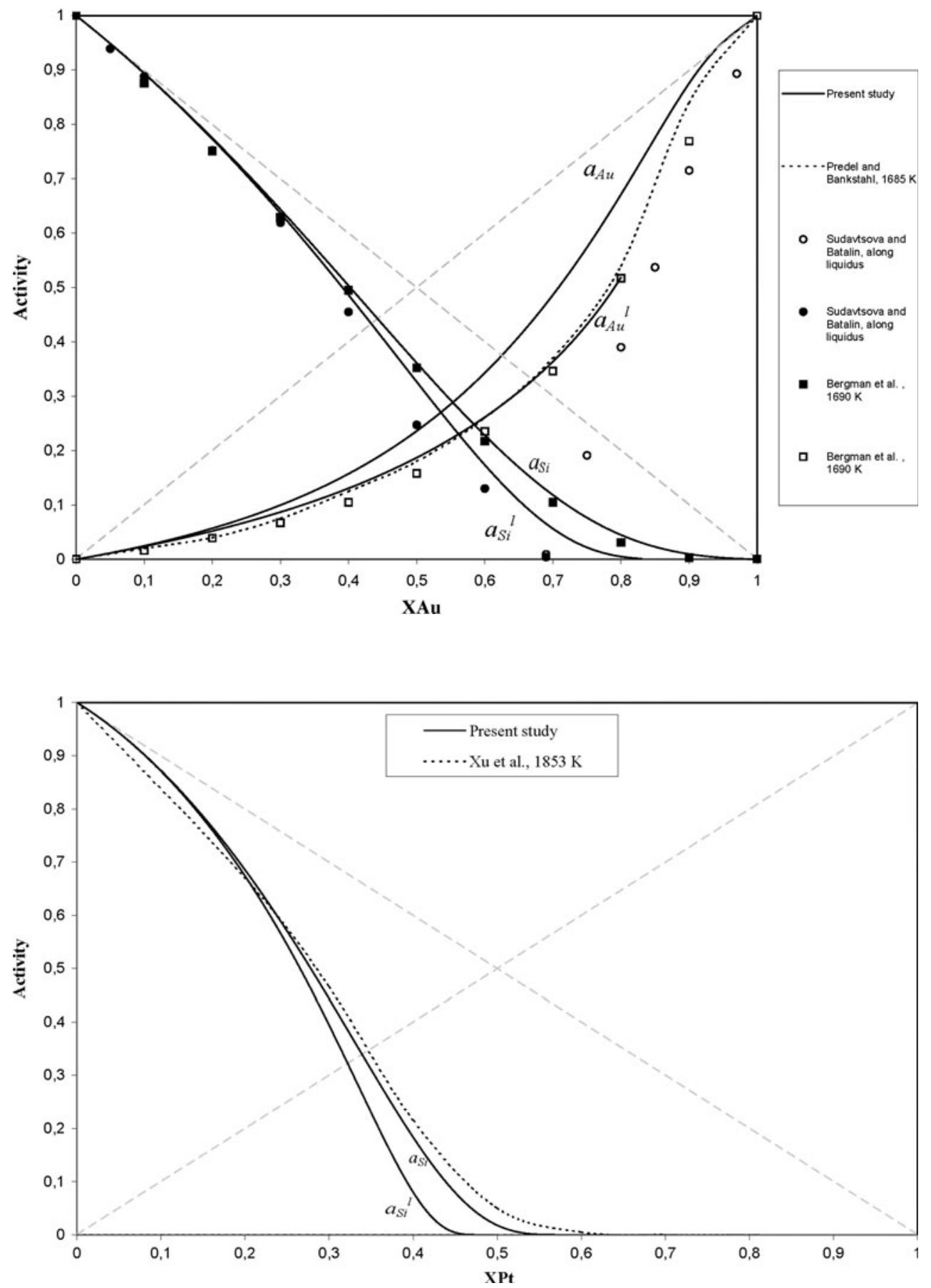

calculated activities for $\mathrm{Si}$ are reliable. Similar to the $\mathrm{Si}-\mathrm{Ti}$ melts, it is difficult for us to determine the Pt activities in $\mathrm{Si}-\mathrm{Pt}$ melts by Gibbs-Duhem equation graphically and such activities are given here.

\section{Si-Sn alloys}

Figure 12 shows the calculated activities for both $\mathrm{Si}$ and $\mathrm{Sn}$ of the present study. In addition, the calculated activities by Sudavtsova and Kudin [47] are illustrated in this figure.
Obviously, a fairly good agreement is obtained between the present calculations and their reported data. These calculations indicate that $\mathrm{Si}-\mathrm{Sn}$ liquid alloys have large positive deviation from the Raoult's law.

\section{$\mathrm{Si}-\mathrm{Pb}$ alloys}

The $\mathrm{Si}-\mathrm{Pb}$ binary system is different from the above mentioned systems; it contains a monotectic reaction at $1,402{ }^{\circ} \mathrm{C}$ and the system is dominated with a miscibility 
Fig. 12 Activities of $\mathrm{Si}$ and $\mathrm{Sn}$ along the liquidus and at the silicon melting point

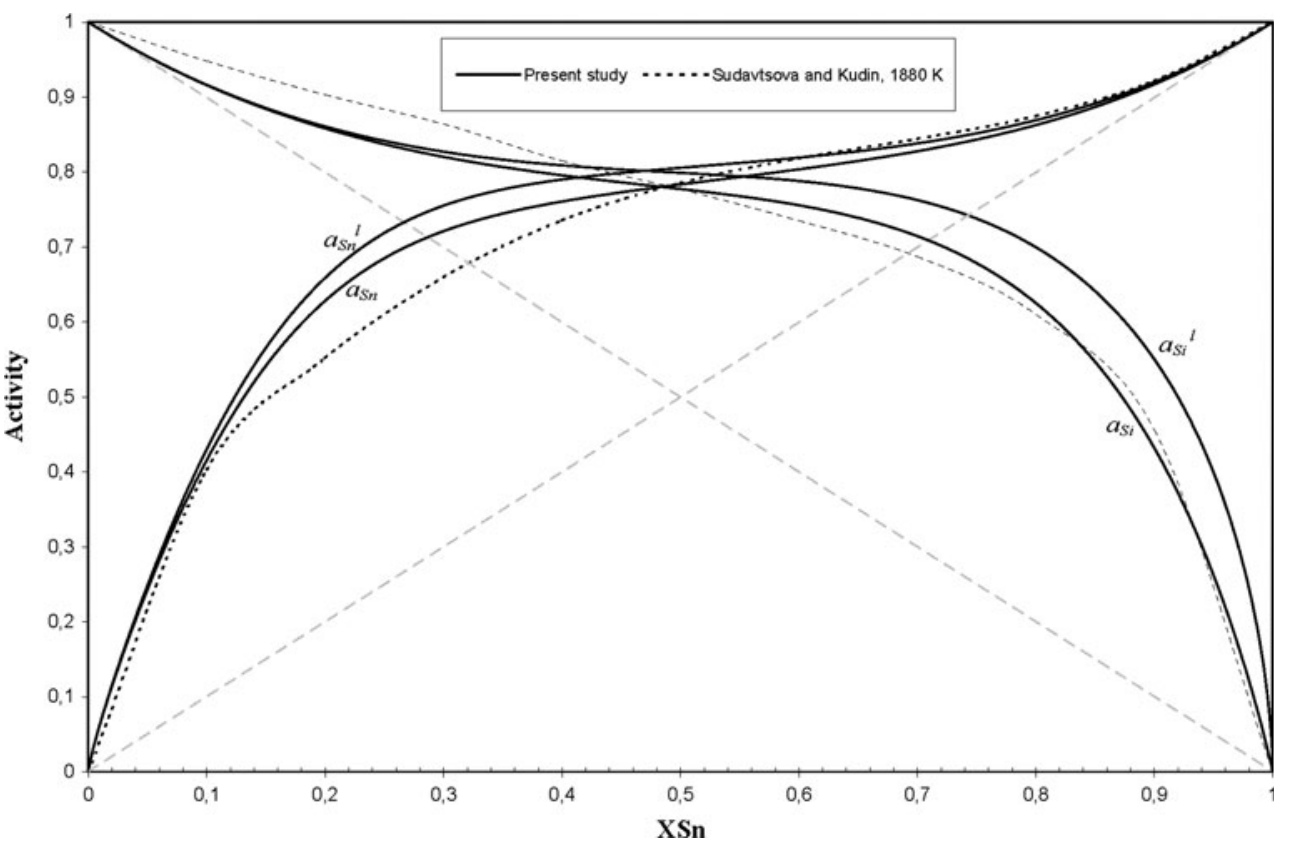

gap in the liquid phase above this temperature in the range of composition between $X_{\mathrm{Pb}}=0.028$ and 0.97 [1]. The calculated activities of the present study for the whole range of composition for both $\mathrm{Si}$ and $\mathrm{Pb}$ are shown in Fig. 13. Activities from pure liquid silicon to $X_{\mathrm{Pb}}=0.031$ were calculated by Eq. (3), which show almost ideal solution behaviour in this range. With the increasing $\mathrm{Pb}$ concentration from $X_{\mathrm{Pb}}=0.031$ where $a_{\mathrm{Pb}}=0.97$, two liquids co-exist, and the activity of $\mathrm{Pb}$ in the whole miscibility gap in the two liquids is equal to 0.97 with regard to pure liquid silicon as the standard state. Silicon activities for $\mathrm{Pb}$-rich melts $\left(\mathrm{X}_{\mathrm{Pb}}>0.97\right)$ shown in Fig. 13 were again calculated by Eq. (3). It is worth noting that no significant difference between the activity values along the liquidus and the constant temperature $\left(1,414^{\circ} \mathrm{C}\right)$ was observed for the $\mathrm{Si}$ - and $\mathrm{Pb}$-rich melts. The $\mathrm{Pb}$ activities in this figure were calculated with similar approach with considering pure liquid $\mathrm{Pb}$ as the standard state. The present calculated activities give $\ln \gamma_{\mathrm{Si}}^{\circ}=4.37$ for Pb-rich melts. However, for Si-rich molten alloys we obtain $\ln \gamma_{\mathrm{Pb}}^{\circ}=3.62$. The results of the calculated activities can be evaluated with regard to the few literature studies as follows. Kirkwood and
Fig. 13 Activities of $\mathrm{Si}$ and $\mathrm{Pb}$ at silicon melting point

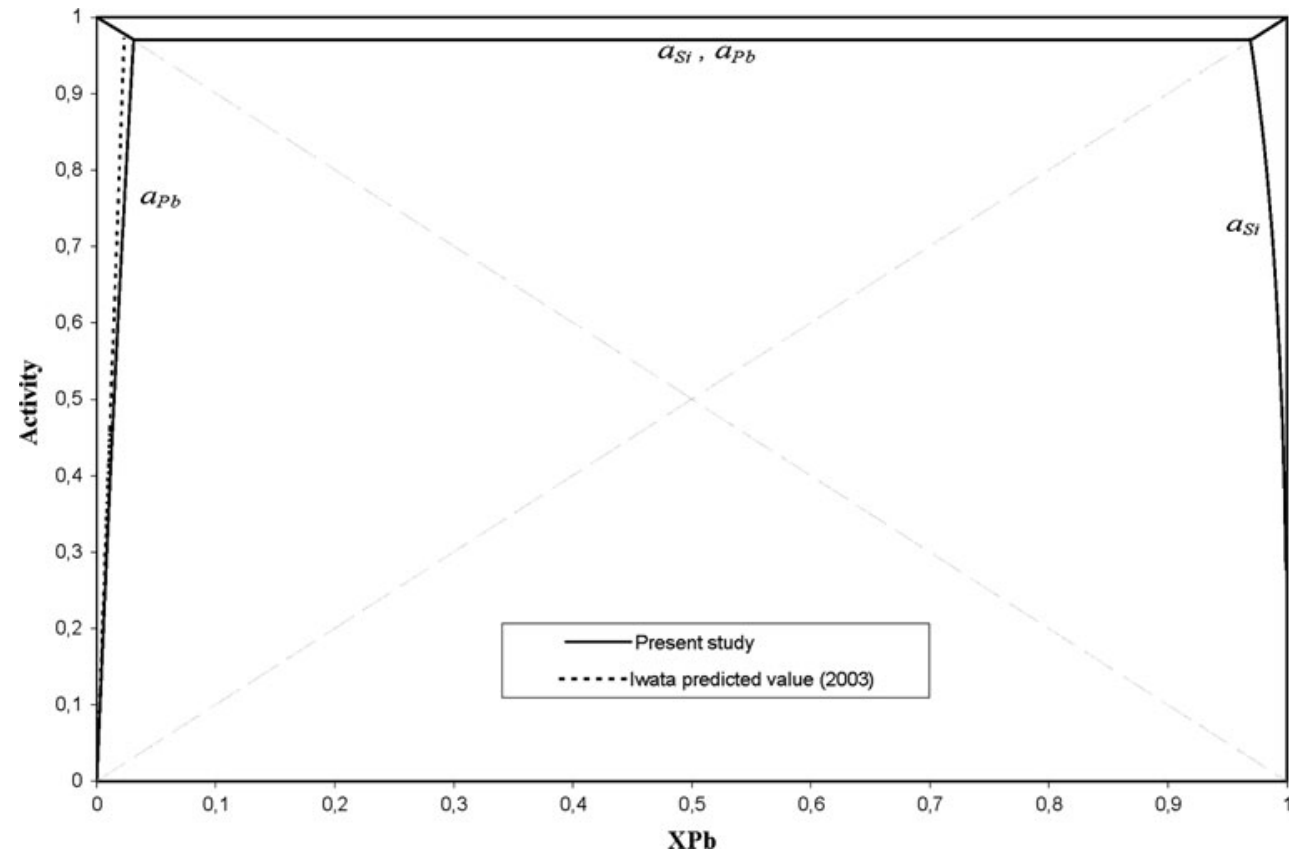


Chipman determined the activity coefficient of silicon in lead-rich $\mathrm{Si}-\mathrm{Pb}$ liquid: $\ln \gamma_{\mathrm{Si}}^{\circ}=3.43$ [48]. The activity coefficient of $\mathrm{Pb}$ in silicon-rich liquid has also been reported as $\ln \gamma_{\mathrm{Pb}}^{\circ}=3.73$ [49]. The interaction coefficient of $\varepsilon_{\mathrm{Pb}}^{\mathrm{Pb}}=0.6$ has been also reported by Iwata et al. [14]. This small value may indicate that changes of activity with composition are not significant, which is seen in Fig. 13. It goes without saying that the present calculated activities are consistent, and the $\mathrm{Si}-\mathrm{Pb}$ liquid solutions show extremely large positive deviations from the Raoult's law. This may indicate why the miscibility gap in a wide range of alloy composition exists. The activities in this area where two liquids are in equilibrium can be estimated as $a_{\mathrm{Si}}=a_{\mathrm{Pb}}=0.97$ (Fig. 13).

\section{Si-Bi alloys}

The $\mathrm{Si}-\mathrm{Bi}$ binary system is similar to the $\mathrm{Si}-\mathrm{Pb}$ system with a miscibility gap in the liquid phase above $1,400{ }^{\circ} \mathrm{C}$ and $X_{\mathrm{Bi}}$ between 0.033 and 0.962 [1]. The calculated activities in $\mathrm{Si}-\mathrm{Bi}$ alloys in this study are shown in Fig. 14. Similar to the $\mathrm{Si}-\mathrm{Pb}$ alloys, both $\mathrm{Bi}$ and $\mathrm{Si}$ show behaviour close to the Raoult's law for their rich alloys and they have large positive deviation from the Raoult's law as dilute solute elements. The activity coefficients of silicon in Birich alloys is estimated as $\ln \gamma_{\mathrm{Si}}^{\circ}=4.03$. This value indicates that the positive deviation of solute silicon in bismuth is extremely high. The activity coefficient of solute $\mathrm{Bi}$ in $\mathrm{Si}$, is constant below $X_{\mathrm{Bi}}=0.02$ and $\ln \gamma_{\mathrm{Bi}}^{\circ}=3.39$. The activities of both $\mathrm{Si}$ and $\mathrm{Bi}$ above $1,400{ }^{\circ} \mathrm{C}$ in the miscibility gap of range of composition are $a_{\mathrm{Si}}=a_{\mathrm{Bi}}=0.962$ refer to the pure liquid substances as the standard states
(Fig. 14). No activity measurement was found comparable with the present calculations.

\section{Si-Sb alloys}

The $\mathrm{Si}-\mathrm{Sb}$ phase diagram is a simple eutectic system and the eutectic transformation is located very close to the pure antimony $[1,50]$. The calculated activities for $\mathrm{Si}-\mathrm{Sb}$ alloys are illustrated in Fig. 15. It is observed that $\mathrm{Si}-\mathrm{Sb}$ molten alloys show positive deviation from the Raoult's law. No experimental activity measurement was found comparable with the calculated activity curves of this study.

\section{Si-Ga alloys}

The calculated activities for $\mathrm{Si}$ and $\mathrm{Ga}$ in $\mathrm{Si}-\mathrm{Ga}$ system, which is a simple eutectic system with eutectic close to the pure Ga [1, 51], are shown in Fig. 16. As we see, these solutions show positive deviation from the ideal solution. The calculated activity curves are comparable with the reported activities by Sudavtsova et al. [52]. They calculated the activities of $\mathrm{Si}$ and $\mathrm{Ga}$ using the measured enthalpies of mixing of $\mathrm{Si}-\mathrm{Ga}$ melts by calorimetry technique.

\section{Si-In alloys}

The $\mathrm{Si}-\mathrm{In}$ phase diagram is a simple eutectic with the eutectic coordinates very close to the pure indium at $X_{\mathrm{Si}}=2.5 \times 10^{-10}$ [1]. The calculated activities for these molten alloys are shown in Fig. 17. Obviously, Si-In melts show positive deviation from the ideal behaviour, and the
Fig. 14 Activities of $\mathrm{Si}$ and $\mathrm{Bi}$ at silicon melting point

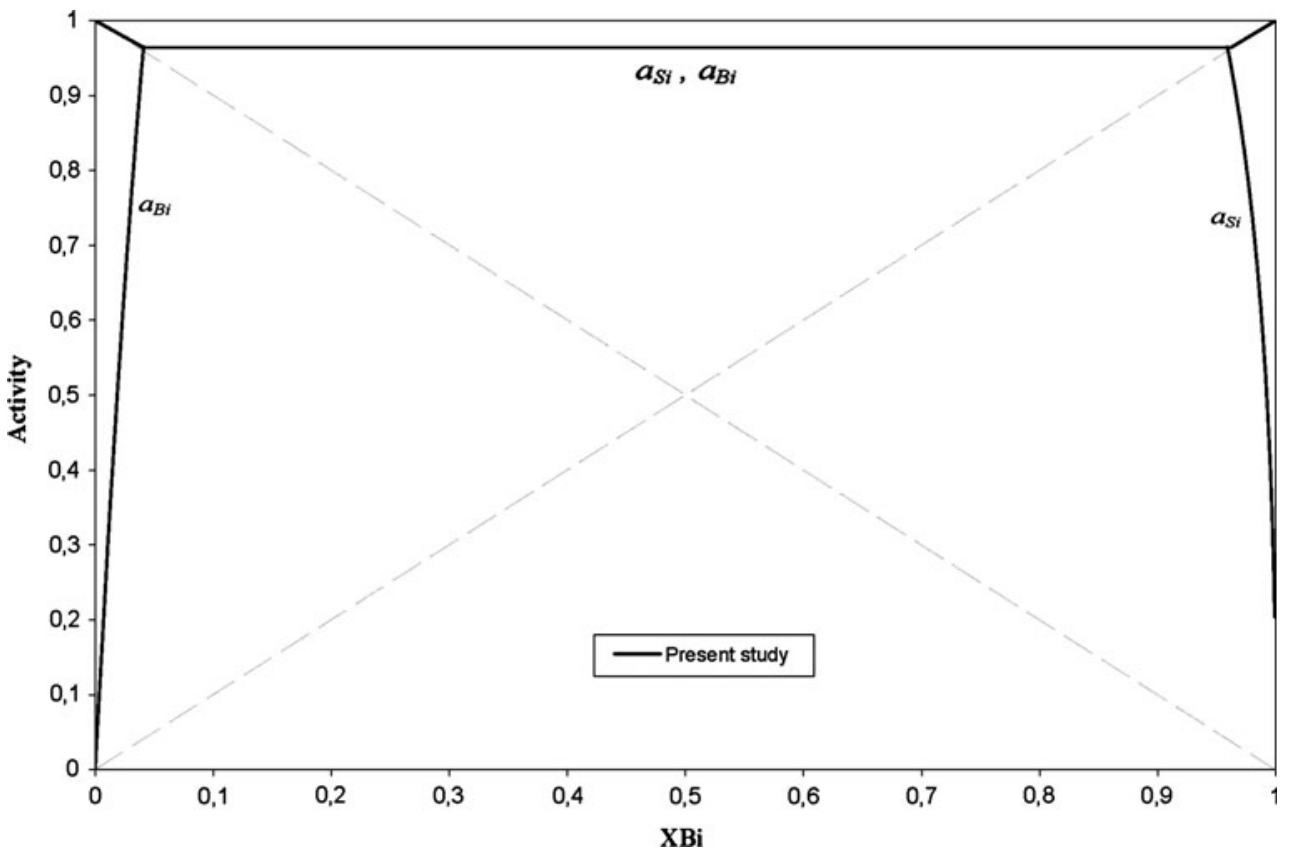


Fig. 15 Activities of $\mathrm{Si}$ and $\mathrm{Sb}$ along the liquidus and at the silicon melting point

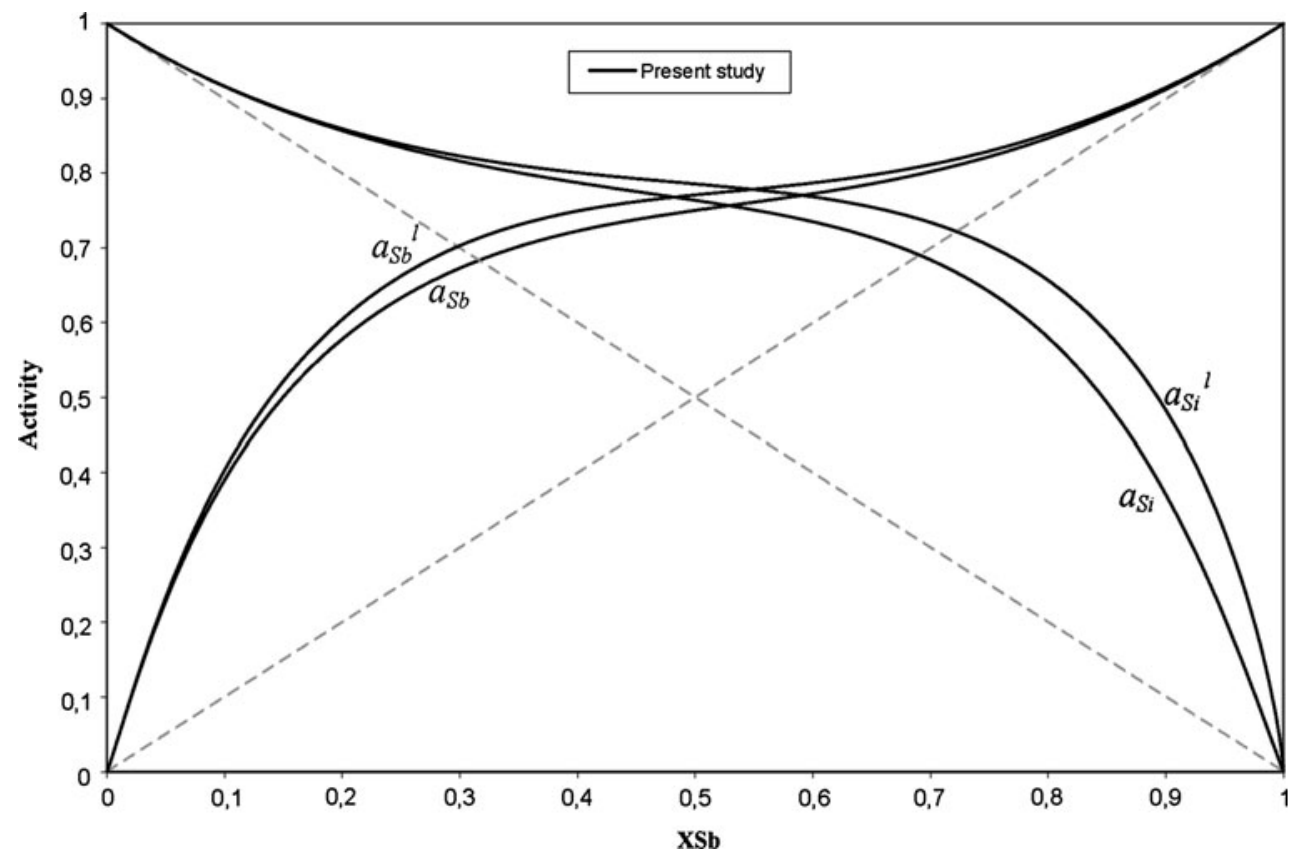

Fig. 16 Activities of $\mathrm{Si}$ and $\mathrm{Ga}$ along the liquidus and at the silicon melting point

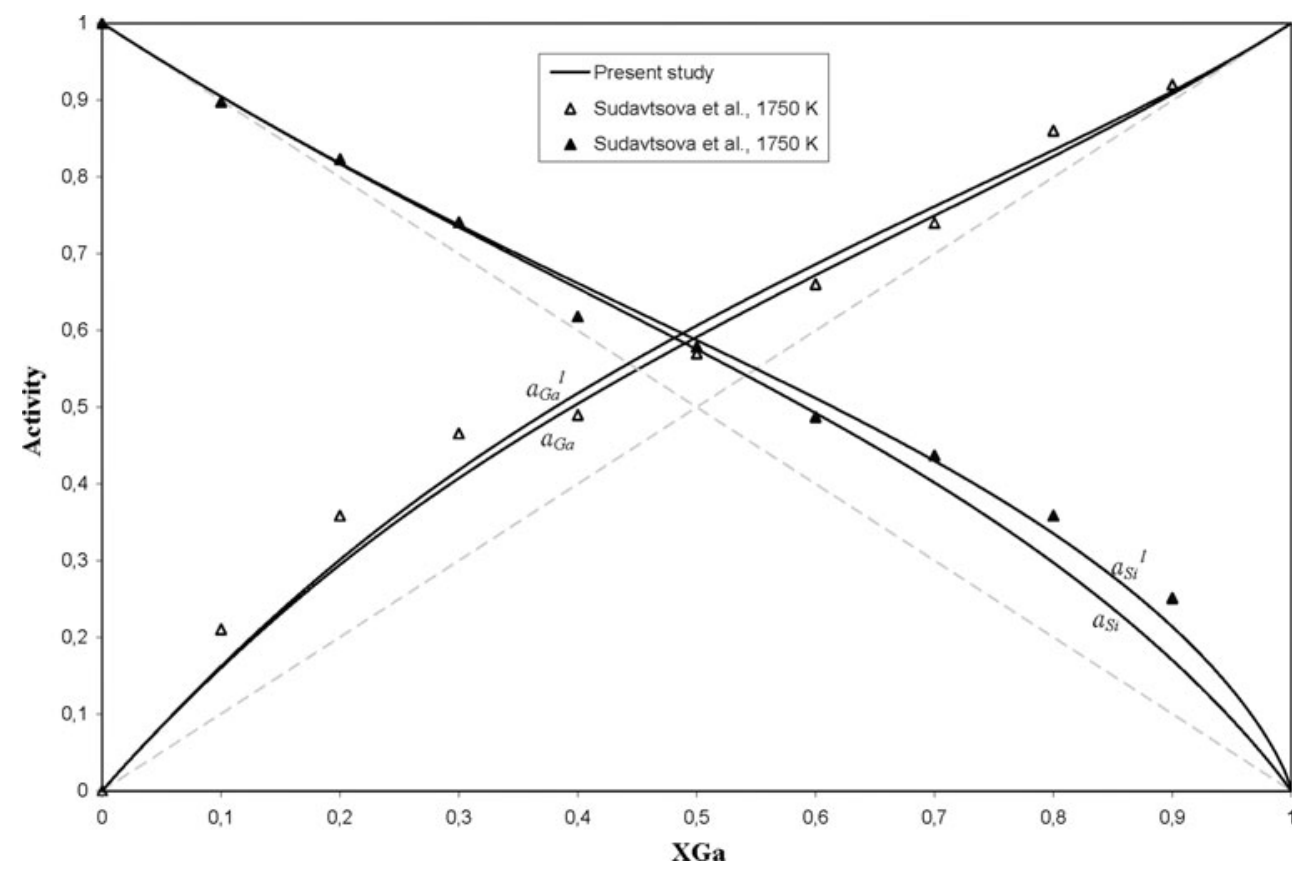

activities of both silicon and indium in their dilute concentrations are large. No literature data were found for $\mathrm{Si}-$ In melts comparable with the present study.

\section{Si-Pd alloys}

Si-Pd binary phase diagram contains many intermediate phases; a eutectic exists between PdSi and Si on the silicon portion at $X_{\mathrm{Si}}=0.52$ [1]. The calculated activities for the components of this system are presented in Fig. 18, and they show that they have negative deviation from the
Raoult's law. No literature data were found for these melts comparable with the present calculations.

\section{Si-Ni alloys}

The Si-Ni binary system contains a peritectic reaction on the silicon side, which is located at $X_{\mathrm{Si}}=0.591$ and $T=1,266 \mathrm{~K}\left(993{ }^{\circ} \mathrm{C}\right)$ between $\mathrm{Si}$ and $\mathrm{NiSi}_{2}$ phases [1]. Activity of silicon in $\mathrm{Si}-\mathrm{Ni}$ melts has been determined by emf technique [53], by emf and calorimetry [54] and by silicon distribution measurement in $\mathrm{Si}-\mathrm{Ni}-\mathrm{Ag}$ alloys [55]. 
Fig. 17 Activities of $\mathrm{Si}$ and $\mathrm{In}$ along the liquidus and at the silicon melting point
Fig. 18 Activities of $\mathrm{Si}$ and $\mathrm{Pd}$ along the liquidus and at the silicon melting point
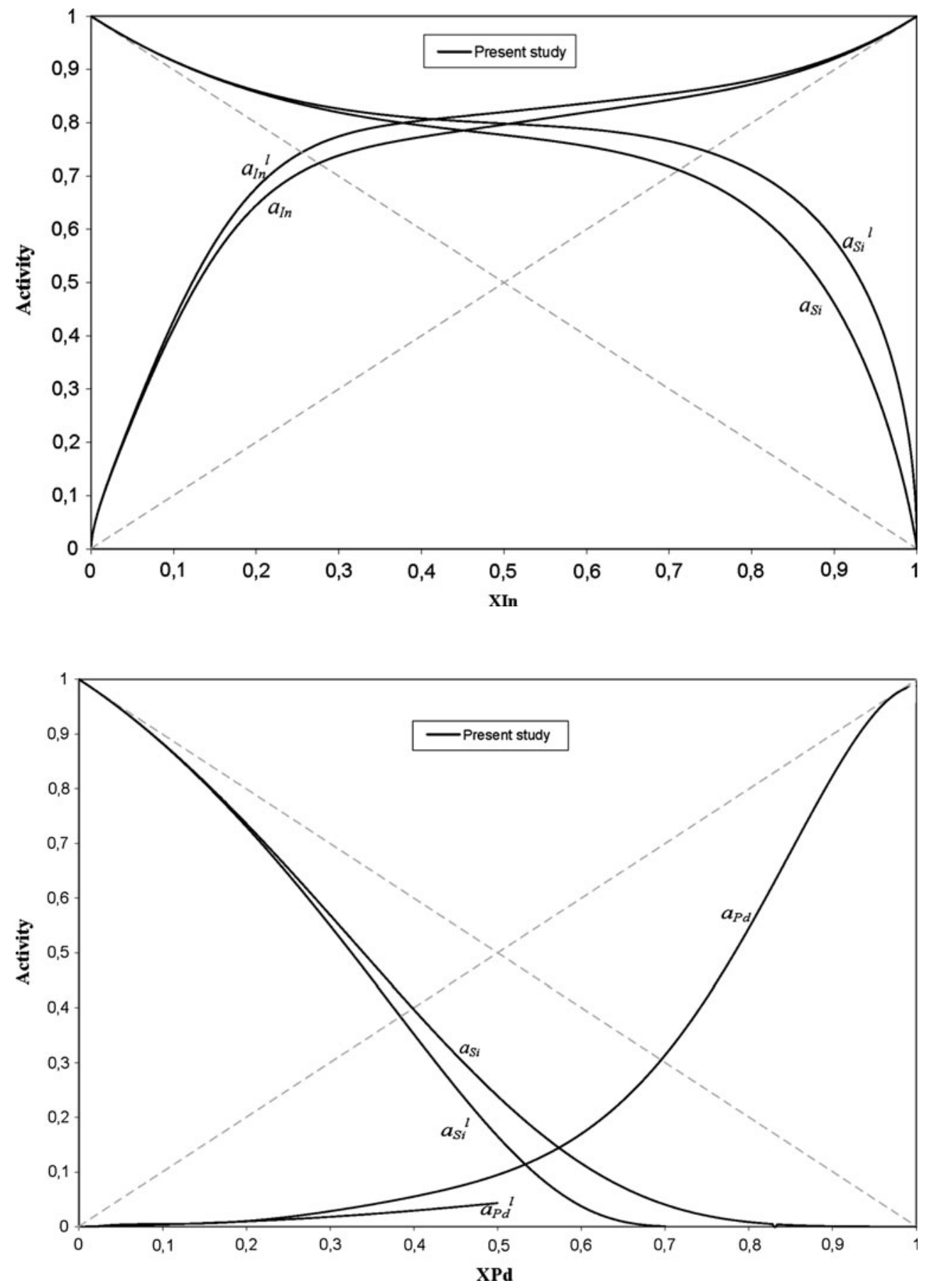

Schwerdtfeger and Engell [53] calculated the Ni activities by graphical Gibbs-Duhem integration. The activities of $\mathrm{Si}$ in $\mathrm{Si}-\mathrm{Ni}$ melts have also been calculated through recent thermodynamic calculations [56-58]. The calculated activities for $\mathrm{Ni}$ and $\mathrm{Si}$ of the present study are plotted in Fig. 19, which are compared with the literature studies. This figure shows that $\mathrm{Si}-\mathrm{Ni}$ liquid alloys have negative deviation from the ideal solution. The calculated silicon activities here are fairly in agreement with the reported activity measurements of the other studies [53-55]. The calculated activities for nickel by graphical Gibbs-Duhem integration are larger than the reported activities proposed by Schwerdtfeger and Engell [53] for low nickel concentrations, while they fit their data in high nickel concen trations.

\section{Si-Mn alloys}

The activities of $\mathrm{Mn}$ and $\mathrm{Si}$ in $\mathrm{Si}-\mathrm{Mn}$ have been measured through emf technique [59], manganese vapour pressure 
Fig. 19 Activities of $\mathrm{Si}$ and $\mathrm{Ni}$ along the liquidus and at the silicon melting point

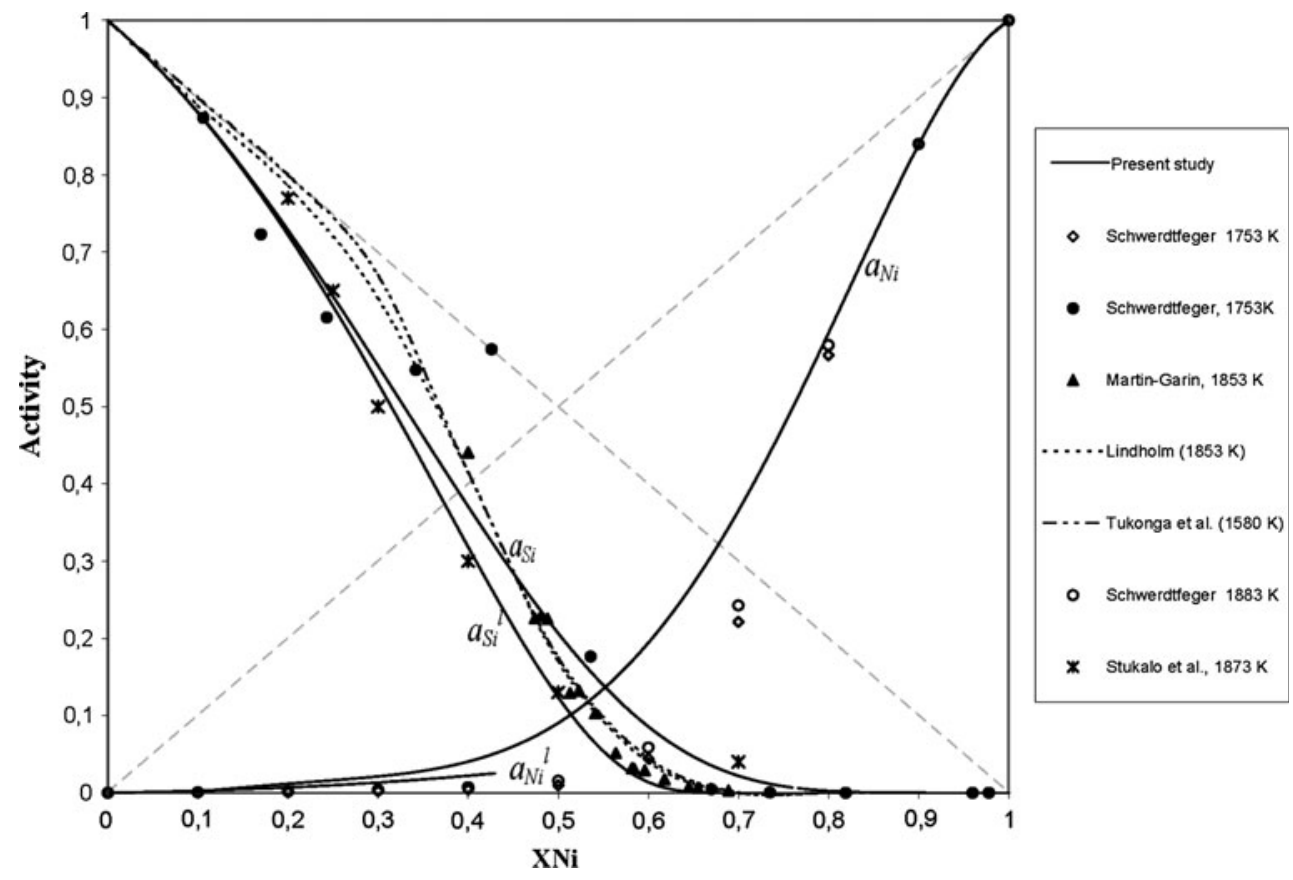

measurements over the melts [60-62] and by torsioneffusion technique [63]. The measured activities through these studies are significantly different, and as seen in Fig. 20, the determined activities by vapour pressure measurements [60, 61] are smaller than the determined activities using the same technique [62] and other techniques [59, 63]. The activities in the $\mathrm{Si}-\mathrm{Mn}$ liquid alloys have also been calculated through thermodynamic studies $[64,65]$. The calculated activities for $\mathrm{Si}$ and $\mathrm{Mn}$ are shown in Fig. 20, which are compared with the literature data. Strong negative deviation for the Si-Mn melts from the ideal solution is observed. The calculated silicon activities are consistent with the literature data [59, 62, 63], and the corresponding calculated Mn activities are in agreement with the literature; however, smaller Mn activities than the literature are obtained in low Mn concentrations.

\section{Si-Rh alloys}

The $\mathrm{Si}-\mathrm{Rh}$ binary system has a eutectic point on the silicon side at $X_{\mathrm{Si}}=0.793$ at $1,333 \mathrm{~K}\left(1,060{ }^{\circ} \mathrm{C}\right)$. The calculated silicon activities to this eutectic composition are shown in
Fig. 20 Activities of $\mathrm{Si}$ and $\mathrm{Mn}$ along the liquidus and at the silicon melting point

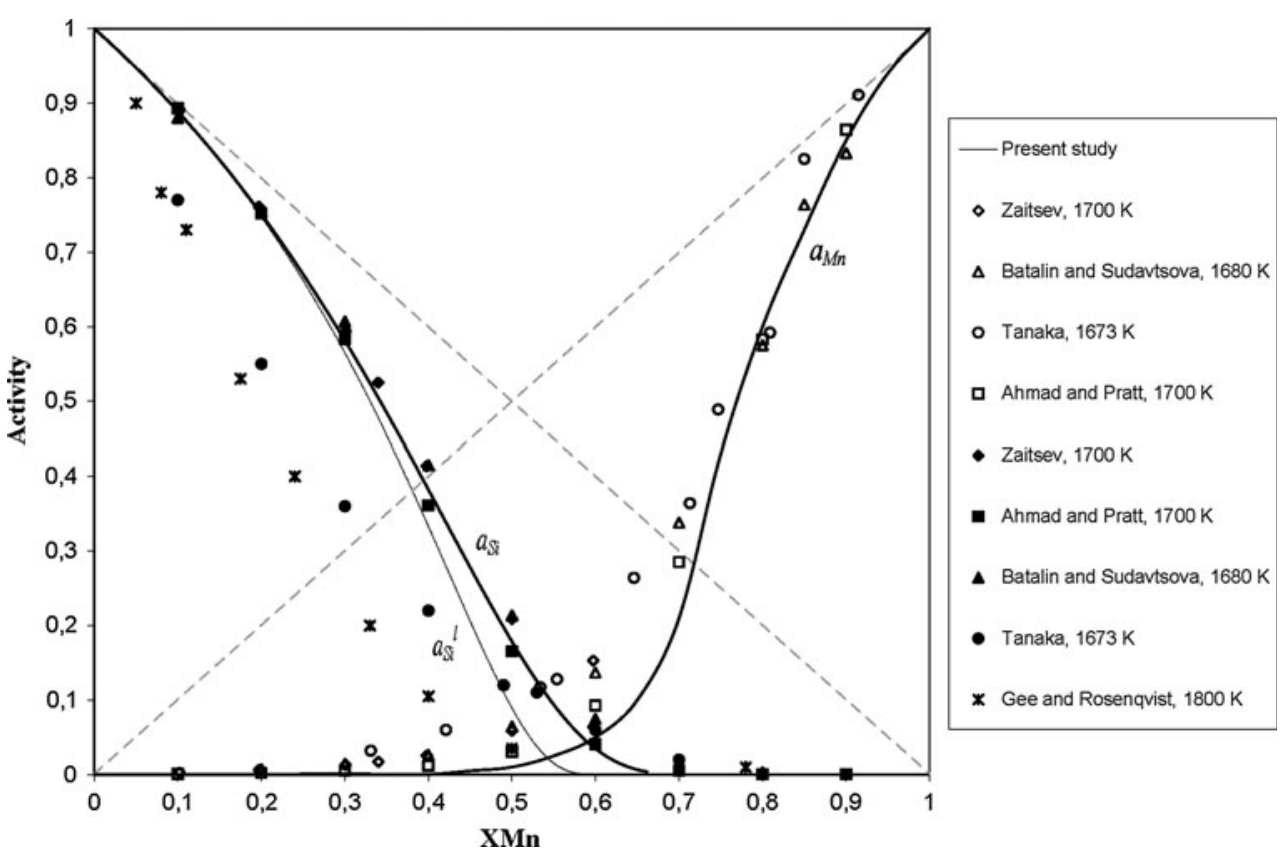


Fig. 21. The calculated silicon activity curves are significantly far from the determined silicon activities by Novoselov et al. [66]. They obtained the silicon activities through the measurement of the $\mathrm{Si}$ vapour pressure over $\mathrm{Si}-\mathrm{Rh}$ melts at $1,700{ }^{\circ} \mathrm{C}$. Their calculations are probably in low accuracy due to the relatively low silicon vapour pressure under their experimental conditions, which is around $2.82 \mathrm{~Pa}$ at $1,700{ }^{\circ} \mathrm{C}$. The calculated activities here are, however, based on the liquidus data and they may be more accurate. The calculated activities indicate very large deviation from the ideal solution for the $\mathrm{Si}-\mathrm{Rh}$ melts. The activities of $\mathrm{Rh}$ in these melts were not calculated because of the difficulties in graphical Gibbs-Duhem integration in low silicon concentrations.

Evaluation of the calculated activities

The calculated activities of the present study and their comparison with the literature data indicate that the applied methodology can be used properly to determine the thermodynamic activities in silicon binary melts. The calculated silicon activities along the liquidus and at the silicon melting point for the silicon binary alloys with $\mathrm{Al}, \mathrm{Ag}, \mathrm{Au}$, $\mathrm{Sn}, \mathrm{Pb}$ and $\mathrm{Ga}$ are consistent with the reported data in literature. Moreover, the calculated activities for the other melt component through Gibbs-Duhem integration are also in agreement with literature data. All these binary alloys are simple eutectic systems containing no intermediate phases. This may accordingly indicate that the calculated activities for the similar silicon binary systems with $\mathrm{Zn}, \mathrm{Bi}$, $\mathrm{Sb}$ and $\mathrm{In}$ are reliable too.
The calculated silicon activities along the liquidus for the silicon binary systems containing intermediate phases such as $\mathrm{Si}-\mathrm{Ca},-\mathrm{Mg},-\mathrm{Fe},-\mathrm{Ti},-\mathrm{Cu},-\mathrm{Ni}$ and $-\mathrm{Mn}$ systems are in agreement with regard to the literature data. Hence, the calculated silicon activities along the liquidus for $\mathrm{Si}-\mathrm{Pt}$, $-\mathrm{Pd}$ and $-\mathrm{Rh}$ melts are expected to be reliable. The silicon activities in the melts under isothermal conditions, i.e. $1,414{ }^{\circ} \mathrm{C}$, are always in a small scale higher than what we obtain along the liquidus. The difference between these activities increases with decreasing silicon concentration due to the temperature decrease along the liquidus and its effect to the Eq. (4). A proper correlation between the calculated activities at $1,414{ }^{\circ} \mathrm{C}$ with the experimentally measured activities at different temperatures was observed for the binary melts which indicates that the activity of silicon in its binary systems is not significantly affected by temperature, while it is strongly dependent on the chemical composition. The calculated activities for the other melt component of the melts were consistent with the majority of the literature data, relying on the properly calculated silicon activities. The effect of the preliminary calculated silicon activity on the calculation accuracy of the other component activity is illustrated for the $\mathrm{Si}-\mathrm{Cu}$ melts. This case indicates that the applied calculation method is very sensitive to the initially calculated silicon activities.

\section{The behaviour of the silicon melts}

A correlation between the thermodynamics behaviour of the silicon binary melts and the metallic properties of the other element is found in this study. The binary melts
Fig. 21 Activity of Si along the liquidus and at the silicon melting point in $\mathrm{Si}-\mathrm{Rh}$ melts

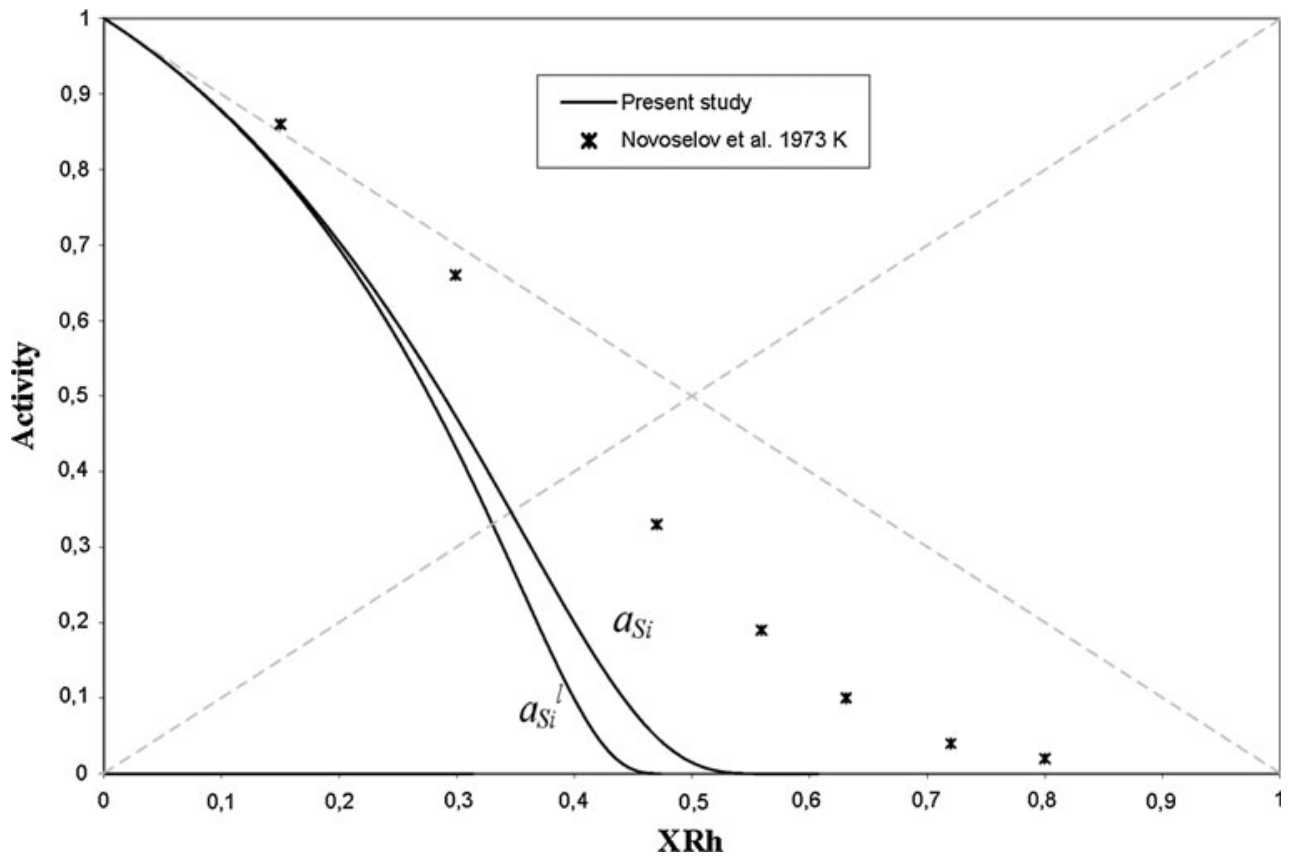


consisted of silicon and alkali earth metals $(\mathrm{Ca}, \mathrm{Mg})$ and transition metals (Ti, Fe, Mn, Ni, Cu, Rh, Pd, Au, Pt) show always negative deviation from the ideal solution. The phase diagram studies of these binary systems show that intermediate compounds exist between these elements and silicon. This may indicate that relatively strong forces exist between the components of their melts which causes the activity drop of each element because of the introduction of the other element; in other words, the negative behaviour compared to the ideal solution. This can be the reason for observing larger deviations for the silicon binary melts formed by the elements in higher period number and lower group number in the periodic table.

The binary melts consisting of silicon and poor metals ( $\mathrm{Zn}, \mathrm{Al}, \mathrm{Ga}, \mathrm{Sn}, \mathrm{Pb}, \mathrm{Bi}$, In and $\mathrm{Sb}$ ) show positive deviation from the ideal solution. It is seen that the phase diagrams of these binary systems contain no silicide, meaning the absence of significant forces between the solution atoms in the melts. Small positive deviation from the ideal solution is observed when the melt consisted of silicon and poor metals with close position to silicon in the periodic table such as $\mathrm{Al}$, and $\mathrm{Ga}$. In contrast 5 , large positive deviation is seen when the metal is far from silicon, such as $\mathrm{Pb}$ and $\mathrm{Bi}$. The presented argument here may be supported considering the behaviour of silver in $\mathrm{Si}-\mathrm{Ag}$ melts, where it shows positive deviation and also negative deviation from the ideal solution. According to the argument here, silver is located in between the transition metals and poor metals in the periodic table and this behaviour of silver is expected.

Activity coefficients in the dilute solutions

The activity data of the dilute solutions of silicon binary melts is important for many metallurgical processes. In particular, the activity of elements in dilute solution with silicon solvent is important for molten silicon treatment in the production of solar grade silicon. Since the activity curves for both components of the silicon binary melts were calculated for the whole range of composition, except for $\mathrm{Si}-\mathrm{Ti}, \mathrm{Si}-\mathrm{Pt}$ and $\mathrm{Si}-\mathrm{Rh}$ melts, the activities in the dilute solutions can be determined. The graphically determined activity coefficients for silicon in different elements $\left(\gamma_{\mathrm{Si}}^{\circ}\right)$ at the silicon melting point are summarized in Table 2. It is worth mentioning that some of the related solvent elements are in the solid state at this temperature and we consider their hypothetical molten states; the reported values are referenced to the pure liquid silicon as the standard state. The obtained activity coefficients for the elements in molten silicon $\left(\gamma_{\mathrm{Me}}^{\circ}\right)$ with graphical approach are also listed in Table 2, which are equally obtained from both calculated activity curves along the liquidus and at the silicon melting point. The activity of some solute elements in molten silicon can also be calculated through a fair approximation on the $\alpha$-value in Eq. (1). The $\alpha$-value for the binary systems of $\mathrm{Si}-\mathrm{Al},-\mathrm{Ca},-\mathrm{Zn},-\mathrm{Sn},-\mathrm{Pb},-\mathrm{Bi},-\mathrm{Sb}$, $-\mathrm{Ga}$ and In is weakly changed along the liquidus and it is constant close to the melting point of silicon. Therefore, considering $T$ in Eq. (1) equal to the silicon melting point $\left(T_{f}, \quad S i\right)$, and applying the Gibbs-Duhem equation $\left(X_{\mathrm{Si}} \mathrm{dln} \gamma_{\mathrm{Si}}+X_{\mathrm{Me}} \mathrm{dln} \gamma_{\mathrm{Me}}=0\right)$ we obtain Eq. (9) to calculate the activity coefficient of the solute element in silicon in low concentrations.

$\ln \gamma_{\mathrm{Me}}=\frac{a-b T_{\text {fus }, \mathrm{Si}}}{R T_{\text {fus }, \mathrm{Si}}}\left(1-X_{\mathrm{Me}}\right)^{2}$

Since for the infinite dilute solutions $X_{\mathrm{Me}} \rightarrow 0$ and $\ln \gamma_{\mathrm{Me}} \rightarrow \ln \gamma_{\mathrm{Me}}^{\circ}$, Eq. (9) can be simplified as

$\ln \gamma_{\mathrm{Me}}^{\circ}=\frac{a-b T_{\mathrm{fus}, \mathrm{Si}}}{R T_{\mathrm{fus}, \mathrm{Si}}}$

The activity coefficients in the above mentioned silicon dilute solutions were calculated by Eq. (10), and the obtained results are presented in Table 2. It is seen that the calculated activity coefficients by this formula are consistent with those obtained graphically.

Applicability of the model

As indicated above, the calculated activities for the $\mathrm{Si}$ binary melts through the outlined model in this study are

Table 2 Activity coefficients of the $\mathrm{Si}-\mathrm{Me}$ dilute solutions at $1,414{ }^{\circ} \mathrm{C}$

\begin{tabular}{llll}
\hline Si-Me melt & $\begin{array}{l}\gamma_{\text {Si From }}^{\circ} \\
\text { activity curve }\end{array}$ & $\begin{array}{l}\gamma_{\text {Me From }}^{\circ} \\
\text { activity curve }\end{array}$ & $\begin{array}{l}\gamma_{\text {Me }}^{\circ} \text { From } \\
\text { Eq. }(10)\end{array}$ \\
\hline $\mathrm{Si}-\mathrm{Al}$ & 0.4184 & 0.370 & 0.3173 \\
$\mathrm{Si}-\mathrm{Ca}$ & 0.004 & 0.0032 & 0.0026 \\
$\mathrm{Si}-\mathrm{Mg}$ & 0.0015 & 0.0498 & - \\
$\mathrm{Si}-\mathrm{Fe}$ & 0.0017 & 0.014 & - \\
$\mathrm{Si}-\mathrm{Zn}$ & 3.0 & 1.4705 & 1.1349 \\
$\mathrm{Si}-\mathrm{Cu}$ & 0.0025 & 0.1865 & - \\
$\mathrm{Si}-\mathrm{Ag}$ & 0.275 & 2.703 & - \\
$\mathrm{Si}-\mathrm{Au}$ & 0.060 & 0.204 & - \\
$\mathrm{Si}-\mathrm{Sn}$ & 7.143 & 5.128 & 5.6813 \\
$\mathrm{Si}-\mathrm{Pb}$ & 78.919 & 37.481 & 37.4806 \\
$\mathrm{Si}-\mathrm{Bi}$ & 56.24 & 29.680 & 29.6853 \\
$\mathrm{Si}-\mathrm{Sb}$ & 4.170 & 4.879 & 5.6865 \\
$\mathrm{Si}-\mathrm{Ga}$ & 1.869 & 1.749 & 1.6275 \\
$\mathrm{Si}-\mathrm{In}$ & 8.0 & 5.598 & 5.2792 \\
$\mathrm{Si}-\mathrm{Pd}$ & 0.030 & 0.0286 & - \\
$\mathrm{Si}-\mathrm{Ni}$ & 0.00035 & 0.0205 & - \\
$\mathrm{Si}-\mathrm{Mn}$ & 0.00025 & 0.0030 & - \\
\hline
\end{tabular}


consistent with experimental measurements in literature. In the present study, 20 Si-binary melts were studied, and the model is applicable for studying other Si binary systems except those show significant solid solubility in silicon such as $\mathrm{Si}-\mathrm{B}, \mathrm{Si}-\mathrm{P}$ and $\mathrm{Si}-\mathrm{As}$ systems. The model may be applicable for studying other similar binary systems in which negligible solid solubility in one melt component is observed. And this element must show negligible changes in the heat capacity due to fusion, which was considered to derive the main Eq. (1). Authors believe that the model is applicable for the binary systems of the elements in the same group with silicon ( $\mathrm{Ge}, \mathrm{In}, \mathrm{Sn}, \mathrm{Pb}$ ). Precise study must be dedicated to other binary melts to evaluate the model applicability for other systems.

\section{Conclusions}

The activities of 20 Si-binary systems were calculated considering the liquidus data on the silicon portion of the phase diagrams, where the activity coefficient of silicon along the liquidus can be calculated using the previously calculated liquidus constants. Silicon activities at the silicon melting point were further calculated through regular solution assumption, which were then used to calculate the other melt component activities by Gibbs-Duhem integration. It was found that the calculated activities of this study are consistent with the measured and calculated activities in the literature. A correlation between the behaviour of the Si-binary melts and the position of the other melt element in the periodic table was observed. In this case, Si-binary melts with alkali and transition metals show negative deviation from the ideal solution, whereas the melts consisting of poor metals show positive deviation from the ideal solution. The activities of the dilute solute elements in the melts were also determined graphically and tabulated. In addition, the activities of particular dilute solute elements in silicon were calculated through a derived simple formula and the results were found to be consistent with the graphically determined values.

Acknowledgements The authors acknowledge the fund provided through the BASIC project (191285/V30) by the Norwegian Research Council.

Open Access This article is distributed under the terms of the Creative Commons Attribution License which permits any use, distribution, and reproduction in any medium, provided the original author(s) and the source are credited.

\section{References}

1. Safarian J, Kolbeinsen L, Tangstad M (2011) Metall Trans B $42 \mathrm{~B}: 852$
2. Thurmond CD, Kowalchik M (1960) Bell Syst Tech J 39:169

3. Gaskell DR (2008) Introduction to the thermodynamics of materials, 5th edn. Taylor \&Francis Group, New York

4. Lupis CHP (1983) Chemical thermodynamics of materials. Massachusetts Institute of Technology, Cambridge

5. Batalin GI, Beloborodova EA, Stukalo VA (1971) Izv Akad Nauk SSSR Met 69:44

6. Mitani H, Nagai H (1967) J Jpn Inst Met 31:1296

7. Loseva AF, Al'mukhamedov AI, Tyumentsev VN, Luzhnova MA (1977) Russ J Phys Chem 51:495

8. Chatillon C, Allibert M (1975) High Temp High Press 7:583

9. Miki T, Morita K, Sano N (1998) Metall Mater Trans B 29B:1043

10. Miki T, Morita K, Sano N (1999) Mater Trans Jpn Inst Met 40:1108

11. Tuset JKr (1985) In: International seminar on refining and alloying of liquid aluminium and ferro-Alloys, 26-28 August, Trondheim, pp 51

12. Kostov A, Zivkovic D, Friedrich B (2007) J Min Met 43B:29

13. Gizenko NV, Emlin BI, Kilesso SN, Gasik MI, Zavyalov AL (1983) Russ Metall 1:29

14. Iwata K, Matsumiya T, Sawada H, Kawakami K (2003) Acta Mater 51:551

15. Wynnyckyj JR, Pidgeon JM (1971) Metall Trans 2:975

16. Schurmann E, Funders P, Litterscheidt H (1975) Arch Eisenhuttenwes 46:473

17. Sudatsova VS, Batalin GI (1988) Izv Akad Nauk SSSR Mater 24:1352

18. De-Oliviera Pinto EC, Takano C (2000) Metall Mater Trans B 31B: 1267

19. Anglezio JC, Servant C, Ansara I (1994) Calphad 18:273

20. Gröbner J, Chumak I, Schmid-Fetzer R (2003) Intermetallics 11:1065

21. Morita K, Miki T (2003) Intermetallics 11:1111

22. Eldridge J, Miller E, Komarek KL (1967) Trans Met Soc AIME 239:775

23. Geffken R, Miller E (1968) Trans Met Soc AIME 242:2323

24. Sryvalin IT, Esin OA, Lepinskikh BM (1964) Russ J Phys Chem 38:637

25. Rao YK, Belton GR (1981) In: Gokcen NA (ed) Chemical Metallurgy - a tribute to carl wagner. TMS-AIME, Warrendale, p 75

26. Chipman J, Fulton JC, Gokcen N, Caskey GR (1954) Acta Metall 2:439

27. Fruehan R (1970) Met Trans 1:865

28. Batalin GI, Sudavtsova VS (1975) J Phys Chem 49:1672

29. Miki T, Morita K, Sano N (1997) Metall Mater Trans B 28B:861

30. Sudavtsova VS, Batalin GI, Tutevich VS (1985) Izv Akad Nauk SSSR 21:779

31. Castanet R (1979) J Chem Thermodyn 11:787

32. Batalin GI, Sudavtsova VS (1982) Izv Akad Nauk SSSR 18:155

33. Witusiewicz V, Arpshofen I, Sommer F (1997) Z Metallkd 88:866

34. Sano K, Okajima K, Okuda N (1956) Mem Fac Eng Nagoya Univ $8: 127$

35. Bergman C, Chastel R, Mathieu JC (1986) J Chem Thermodyn 18:835

36. Sommer F, Choi DK, Predel B (1989) Z Metallkd 80:366

37. Hager JP (1963) Trans Met Soc AIME 227:1000

38. Turkdogan ET, Grieveson P (1963) Trans Met Soc AIME 227:1143

39. Vermande A, Ansara I, Desre P (1970) Rev Int Hautes Temper et Refract 7:39

40. Robinson VS, Tarby SK (1971) Metall Trans 2:1347

41. Sakao H, Elliot JF (1974) Metall Trans 5:2063

42. Predel B, Bankstahl H (1975) J Less-Common Met 43:191

43. Sudavtsova VS, Batalin GI (1977) Ukr Khim Zh 3:235 
44. Bergman C, Chastel R, Gilbert M, Castanet R (1978) High Temp High Press 10:581

45. Elliot RP, Shunk EA (1981) Bull Alloy Phase Diagr 2:359

46. Xu LL, Wang J, Liu HS, Jin ZP (2008) Comput Coup Phase Diagr Thermochem 32:101

47. Sudavtsova VS, Kudin VG (2001) Inorg Mater 37:319

48. Kirkwood D, Chipman J (1961) J Phys Chem 65:1082

49. Shimpo T, Yoshikawa T, Morita K (2004) Metall Mat Trans B 35B: 277

50. Olesinski RW, Abbaschian GJ (1985) Bull Alloy Phase Diagr $6: 445$

51. Olesinski RW, Kanani N, Abbaschian GJ (1985) Bull Alloy Phase Diagr 6:362

52. Sudavtsova VS, Zinevich TN, Kotova NV, Beloborodova EA (2004) Russ J Phys Chem 78:829

53. Schwerdtfeger K, Engell HJ (1965) Trans Met Soc AIME 233:1327

54. Stukalo VA, Batalin GI, Neshchimenko NYa, Kurach VP (1979) Russ Metall 6:68
55. Martin-Garin L, Ansara I, Desre P (1968) CR Acad Sci Paris 266:1595

56. Lindholm M, Sundman B (1996) Metall Mater Trans A 27A:2897

57. Tokunaga T, Nishio K, Ohtani H, Hasebe M (2003) Comput Coup Phase Diagr Therm 27:161

58. Miettinen J (2005) Comput Coup Phase Diagr Thermochem 29:212

59. Batalin GI, Sudavtsova VS (1975) Inorg Mater 11:1527

60. Gee R, Rosenqvist T (1976) Scand J Metall 5:57

61. Tanaka A (1977) Nippon Kinzoku Gakkaishi 41:601

62. Zaitsev AI, Zemchenko MA, Mogutnov BM (1989) Rasplavy 2:9

63. Ahmad N, Pratt JN (1978) Metall Trans A 9A:1857

64. Kanibolotskii DS, Lesnyak VV (2006) Russ Metall 3:199

65. Shukla A, Kang YB, Pelton AD (2008) Comput Coup Phase Diagr Thermochem 32:470

66. Novoselov BM, Dubinin EL, Timofeev AI, Chegodaev AI, Demidovich OV (1978) Akad Nauk SSSR Ural Nauchn Tsentr Sverdlovsk 2:5 